\title{
The Use AND ABUSE of TRUst: Social CAPITAL AND ITS DEPLOYMENT BY EARLY MODERN GUILDS
}

\author{
SHEILAGH OGILVIE
}

\author{
CESIFO WORKING PAPER NO. 1302 \\ CATEGORY 10: EMPIRICAL AND THEORETICAL METHOdS \\ OCTOBER 2004
}

\footnotetext{
An electronic version of the paper may be downloaded

- from the SSRN website:

www.SSRN.com

- from the CESifo website:

www.CESifo.de
} 


\title{
ThE USE AND ABUSE OF TRUST: SOCIAL CAPITAL AND ITS DEPLOYMENT BY EARLY MODERN GUILDS
}

\begin{abstract}
Guilds are social scientists' favoured historical example of institutions generating a 'social capital' of trust that benefited entire economies. This article considers this view in the light of empirical findings for early modern Europe. It draws the distinction between a 'particularized' trust in persons of known attributes and a 'generalized' trust that applies even to strangers. This is paralleled by the distinction between a 'differential' trust in institutions that enforce the rights of certain groups and a 'uniform' trust in impartial institutions that enforce the rights of all. Guilds had the potential to generate the particularized and differential trust to solve market failures relating to product quality, training, and innovation, although the empirical findings suggest that they often failed to fulfil this potential. Guilds also had the potential to abuse their trust, and the empirical findings show that they indeed manipulated their social capital of shared norms, common information, mutual sanctions, and collective political action to benefit their members at others' expense, blocking the spread of generalized and uniform trust. Counter to the assumptions of social capital theory, the example of preindustrial guilds suggests that the particularized and differential trust fostered by associative institutions do not favour but hinder the generalized and uniform trust fostered by impartial institutions.
\end{abstract}

JEL Code: L4, N43, N63, O17, Z13.

\author{
Sheilagh Ogilvie \\ Faculty of Economics \\ University of Cambridge \\ Sidgwick Avenue \\ Cambridge CB3 9DD \\ United Kingdom \\ sco2@econ.cam.ac.uk
}

I thank André Carus, Partha Dasgupta, Tracy Dennison, Jeremy Edwards, and Tim Guinnane for stimulating discussions of the arguments presented in this essay and exceptionally helpful comments on earlier drafts. I also gratefully acknowledge the support of a British Academy Research Readership during its writing. 
The Use and Abuse of Trust:

\section{$\underline{\text { Social Capital and its Deployment by Early Modern Guilds }}$}

\section{Trust, Social Capital, and History}

The concepts of 'trust' and 'social capital' have enjoyed increasing vogue now for more than a decade. History has been mobilized to support them in various ways. Past societies are often portrayed as having enjoyed more trust than modern ones. History is mined for examples of the closely-knit and multi-stranded social networks thought to generate particularly rich stocks of social capital. ${ }^{1}$ Those modern societies that retain more vestiges of associative networks from their past are regarded as better off than those that depend exclusively on markets and states. ${ }^{2}$ Certain cultures are supposed to have evolved historically so as to foster networks and trust. ${ }^{3}$ Yet while many studies adduce historical examples of social networks in passing, few examine them rigorously, to identify which of their features generated trust, how they deployed their social capital, and what effect this had on their economies. This article seeks to fill this gap, by examining a historical social network frequently adduced as generating trust and social capital: the guild.

\subsection{What is Social Capital?}

Despite their rapid diaspora (or perhaps because of it), the concepts of 'social capital' and 'trust' have fallen prey to a horde of competing definitions. ${ }^{4}$ To be clear about the object of discussion, this article adopts the following definition of 'social capital', which is consistent with classic discussions by James Coleman and Robert Putnam. ' 'Social capital' is a store of value generated when a group of individuals invests resources in fostering a body of relationships with each other (a 'social network'), which generates benefits in later periods. ${ }^{6}$

\footnotetext{
${ }^{1}$ J. S. Coleman, Social Capital in the Creation of Human Capital, in: American Journal of Sociology, 94, 1989, Supplement, pp. S95-S120, here pp. S117-S119; R. D. Putnam / R.. Leonardi / R. Y. Nanetti, Making Democracy Work: Civic Traditions in Modern Italy, Princeton, NJ 1993, esp. pp. 163-85; F. Fukuyama, Trust: The Social Virtues and the Creation of Prosperity, New York 1995, esp. pp. 1-57, 345-53; R. D. Putnam, Bowling Alone: the Collapse and Revival of American Community, New York 2000, pp. 319, 322-3, 325, 346-7.

${ }^{2}$ K. J. Arrow, Observations on Social Capital, in: P. Dasgupta / I. Serageldin (eds.), Social Capital: A Multifaceted Perspective, Washington, 2000, pp. 3-5, here p. 5; Putnam et al., Making Democracy Work, pp. 121, 162.

${ }^{3}$ Fukuyama, Trust, pp. 1-57, 345-53.

${ }^{4}$ Arrow, Observations; R. M. Solow, Notes on Social Capital and Economic Performance, in: Dasgupta / Serageldin, Social Capital, pp. 6-12.

${ }^{5}$ Coleman, Social Capital; Putnam et al., Making Democracy Work.

${ }^{6}$ Scepticism has been expressed about the analogy with capital as it is ordinarily conceived by economists: see Arrow, Observations, p. 4; Solow, Some Notes, pp. 7-8.
} 
The resources invested in social capital reside in relationships within a network rather than in physical objects, financial instruments, or (as with human capital) single individuals. ${ }^{7}$

The returns to social capital are many, in this view, but all fall into one of four categories. ${ }^{8}$ First, social networks foster shared norms, creating expectations of trustworthiness which reduce the transactions costs associated with violation of agreements. ${ }^{9}$ Second, social networks improve information flow, creating the trust necessary to solve market failures caused by incomplete or asymmetric information. ${ }^{10}$ Third, social networks create the trust that facilitates group sanctions against deviations from the network's norms. ${ }^{11}$ Fourth, social networks create the trust that overcomes obstacles to collective political action to monitor government. ${ }^{12}$ Social capital is held to be created when social networks create the trust necessary for correcting failures of markets and states, and this investment pays off in terms of better contract enforcement, information, sanctions, and collective action. The total cost of the investment in social capital, it is claimed, is exceeded by the total benefit flowing from these four sources. ${ }^{13}$

According to this view, all four forms of value associated with social capital - norm fostering, information flow, penalties on deviance, and collective action - have strong 'public good' characteristics: individual investors in social networks enjoy only part of the benefits, so they may under-invest. ${ }^{14}$ This has policy implications: to the extent that social capital exists and is a public good, there is a case for public action to create, subsidize, or privilege social networks, whether to substitute for states or markets or to make them work better. ${ }^{15}$ Increasingly, investing in social capital and social networks - rather than, for instance, effective states and efficient markets - is being recommended as a solution to problems of social exclusion and regional disparities in the rich West, ${ }^{16}$ economic transition in post-

\footnotetext{
${ }^{7}$ Coleman, Social Capital, pp. S97-S101.

${ }^{8}$ Coleman, Social Capital, pp. S100-S101.

${ }^{9}$ Coleman, Social Capital; D. Gambetta, Can We Trust Trust?, in: D. Gambetta (ed.), Trust: Making and Breaking Cooperative Relations, Oxford 1988, pp. 213-37.

${ }^{10}$ Coleman, Social Capital, pp. S101-S102.

${ }^{11}$ Putnam et al., Making Democracy Work; Coleman, Social Capital; D. Narayan / L. Pritchett, Social Capital: Evidence and Implications, in: Dasgupta / Serageldin, Social Capital, pp. 269-95.

${ }^{12}$ Putnam et al., Making Democracy Work; Coleman, Social Capital; Narayan / Pritchett, Social Capital.

${ }^{13}$ The social capital literature generally avoids discussing what these costs must be, but at the least they must include the opportunity cost of the time and other resources devoted to fostering interpersonal relationships within social networks, and in principle they should also include any negative externalities resulting from actions taken by the network. For exceptional contributions that consider the costs as well as the benefits of social capital and trust, see P. Dasgupta, Economic Progress and the Idea of Social Capital, in: Dasgupta / Serageldin, Social Capital, pp. 325-424, here e.g. pp. 327, 344-7, 367; and P. Dasgupta, Social Capital and Economic Progress: Analytics, in: E. Ostrom / T. K. Ahn (eds.), Social Capital: a Reader, Cheltenham 2003, here esp. p. 310.

${ }^{14}$ Coleman, Social Capital, pp. S115-S119; P. Dasgupta, Trust as a Commodity, in: Gambetta, Trust, pp. 49-72, here 64.

${ }^{15}$ United Nations Development Program, Human Development Report 1993, Oxford / New York 1993, p. 8; World Bank, The World Bank and Participation, Washington, 1994, p. i; E. A. Brett, The Participatory Principle in Development Projects: the Costs and Benefits of Cooperation, in: Public Administration and Development, 16, 1996, pp. 5-19, here esp. pp. 5-6.

${ }^{16}$ Coleman, Social Capital; Putnam et al., Making Democracy Work.
} 
communist Eastern Europe ${ }^{17}$ and development challenges in the Third World. ${ }^{18}$ These policy implications mean it is important to look closely at the institutions that create social capital.

What kind of institution fosters social capital? James Coleman, one of the earliest theorists focussing on this question, postulated that the unusual degree of trust associated with 'interesting' social capital - the sort yielding the four pay-offs cited above - is likely to be generated by social arrangements possessing two key features: 'closure' and 'multiplex relationships'. 'Closure' means that network membership is clearly defined, so that members' actions can be easily monitored, norm-violating behaviour effectively punished, and normcompliant behaviour collectively rewarded. 'Multiplex relationships' mean that an organization, 'once brought into existence for one set of purposes, can also aid others'. Many social networks (especially those such as guilds, with long historical roots) are not deliberately 'brought into existence for one set of purposes', but members of the network do engage in repeated transactions with one another, which generally encompass different spheres of activity such as the economic, social, political, and religious. This generates multistranded relationships which endow members with multiple means of getting information about, punishing deviance in, and urging collective action on one another. ${ }^{19}$ Coleman's insights are significant, yet in the spate of publications on social capital and social networks since 1989 they have hardly been pursued. ${ }^{20}$ As this essay will argue, however, European economic history suggests that 'closure' and 'multiplex relationships' are essential for generating social capital and crucial to its broader impact.

\subsection{What is Trust?}

But what is this 'trust' that is so closely associated with the concept of 'social capital'? To be clear about what we are discussing, this essay will adopt the straightforward, ordinarylanguage definition of trust as 'confidence in or reliance on some quality or attribute of a person or thing'. ${ }^{21}$ Social scientists are interested in this confidence or reliance in persons and things because there are strong reasons for believing that without it, economic agents will refrain from engaging in transactions involving certain people, things, or institutions, and

\footnotetext{
${ }^{17}$ M. Raiser, Informal Institutions, Social Capital and Economic Transition, in: G. A. Cornia and V. Popov (eds.), Transition and Institutions. The Experience of Gradual and Late Reformers, Oxford 2001, pp. 218-39; J. Stiglitz, New Bridges across the Chasm: Institutional Strategies for the Transition Economies (World Bank, 8 Dec. 1999). http://wbln0018. worldbank.org/eca/eca.nsf/0/0ac8adc7b03aca0885256847004e2b82? OpenDocument

${ }^{18}$ United Nations Development Program, Human Development Report 1993, esp. p. 8; World Bank, The World Bank and Participation, esp.p. i; Dasgupta / Serageldin, Social Capital.

${ }^{19}$ Coleman, Social Capital, pp. S104-S110.

${ }^{20}$ For an excellent recent exception, see $N$. Molenaers, Associations or Informal Networks? Social Capital and Local Development Practices, in: M. Hooghe / D. Stolle (eds.), Generating Social Capital: Civil Society and Institutions in Comparative Perspective, New York 2003, pp. 113-132, here esp. p. 122.

${ }^{21}$ Compact Oxford English Dictionary, Oxford 1991, p. 2122, panel 623.
} 
mutually beneficial cooperation will go unrealized. ${ }^{22}$ However, this ordinary-language definition of trust only takes us so far.

For one thing, it is ambiguous as to whether 'trust' refers to an inward sentiment or an observable propensity. The sentiment of trust is a feeling or attitude adopted by an economic agent: it is not directly observable by the social scientist, and is at most an input into actions which have outcomes for the economy. Trust as a propensity, by contrast, is just the increased tendency to engage in certain actions: it is observable and it directly gives rise to economic outcomes. Contributors to the literature on social capital often talk in terms of trust as a sentiment, seeking to measure people's feelings of trust and analysing the influences on these feelings. ${ }^{23}$ However, since it is not inputs but outcomes that have social benefits, what social capital theorists are really interested in is trust as an observable propensity to engage in certain actions or enter into certain types of transaction. ${ }^{24}$ Such a propensity may or may not derive from an inward sentiment of trust. It may often derive from a perception that certain social arrangements tend to lead one's transaction partners to behave in a trustworthy way even if, in the absence of these social arrangements, one would not feel a sentiment of trust towards them. Economic historians investigating social capital are primarily interested in outcomes - and also prefer to focus on what is observable - so this essay will concentrate on trust as a propensity rather than as a sentiment.

But even when it is regarded as an observable propensity, the concept of trust is still used in several different ways by social scientists. Before we proceed, we will have to minimize this confusion by making a few important distinctions. First, there are two broad categories of what may be an object of trust: persons and institutions. A propensity to trust in persons is a tendency, for whatever reason, to be willing to enter into transactions with partners having certain personal or group attributes. A propensity to trust in institutions, by contrast, is the tendency to make use of particular mechanisms - guilds, markets, states, communities, churches, manorial systems, masonic lodges, religious clubs, mafias, cartels, or any one of the myriad of mechanisms available in one's society to mediate human relationships. Much of the literature on social capital fails to distinguish between these two manifestations of trust, even though they have quite different policy implications. The social capital literature often assumes, for example, that encouraging trust in persons will give rise to greater trust in institutions, which in turn is invariably regarded as an unambiguously

\footnotetext{
${ }^{22}$ See the discussion of the social and economic significance of trust in Dasgupta, Trust, pp. 49-51, 55, 61; Gambetta, Can We Trust Trust?, pp. 217-20.

${ }^{23}$ See, for instance, Gambetta, Can We Trust Trust?, p. 217; Putnam, Bowling Alone, pp. 134-47. For a criticism of this tendency in the literature on trust and social capital, particularly in the work of Robert Putnam , see Stolle / Hooghe, Conclusion, in: Hooghe / Stolle (eds.), Generating Social Capital, pp. 231-48, here esp. p. 244.

${ }^{24}$ For a clear-sighted discussion focussing on the observable, economically relevant aspect of trust (i.e., what we are terming trust as a propensity), see Dasgupta, Trust, esp. pp. 49-51; and P. Seabright, Is Cooperation HabitForming?, in: P. Dasgupta / K.-G. Mäler (eds.), The Environment and Emerging Development Issues, 2 vols., Oxford 1997, vol. 2, pp. 283-307.
} 
desirable outcome. Yet the process by which trust in persons translates into trust in institutions is never spelled out. Even more worryingly, it is easy to imagine both persons (charismatic dictators, religious zealots, promoters of pyramid schemes) and institutions (mafias, cartels, racist clubs) that attract trust but do not benefit society.

Even before addressing such causal and normative questions, there is a further distinction to be drawn between two very different kinds of trust in persons - a particularized trust in persons of known attributes or affiliations, and a generalized trust that applies even to complete strangers. Particularized trust depends on specific personal attributes or group affiliations of your transaction partner: you are willing to enter into a transaction because you either know your transaction partner personally or she is a member of a group whose other members you trust as a result of knowing their personal attributes. ${ }^{25}$ Generalized trust, by contrast, is a propensity to enter into transactions with all persons on an equal footing, even with strangers - people of whose personal characteristics or group affiliations you are ignorant. It is this generalized trust in strangers which social scientists find particularly interesting, since it is thought to have very wide social and economic benefits. ${ }^{26}$ But the social capital literature, while paying lip service to generalized trust as a desired outcome, actually spends most of its time discussing particularized trust in persons of known attributes and affiliations, and simply assumes that this somehow leads to higher levels of generalized trust. ${ }^{27}$ One purpose of this essay, therefore, is to examine the relationship between a particularized and a generalized trust in persons.

But we must also distinguish between two very different kinds of trust in institutions - a differential trust of institutions with 'closure' (institutions mainly trusted by their members), and a uniform trust of institutions whose provisions apply uniformly to anyone in a given society. Differential trust is a propensity to allow your transactions to be mediated by a particular institution because it can be trusted to enforce your particular rights and privileges. Thus, for instance, an early modern craftsman might have had a propensity to allow his transactions to be mediated by his guild because he trusted it to enforce his particular rights and entitlements as a guild member. Uniform trust, by contrast, is a propensity to allow your transactions to be mediated by an institution because it can be trusted to enforce anyone's rights and privileges in an impartial way, regardless of personal attributes. Thus, for instance, an efficient market or a just state is supposed to mediate the transactions of any economic agent impartially, without regard to any personal characteristic appertaining to the individual

\footnotetext{
${ }^{25}$ For a description of this kind of trust in the context of the Italian mafia, see D. Gambetta, Mafia: the Price of Distrust, in: Gambetta, Trust, pp. 159-75, here pp. 165-6.

${ }^{26}$ For a synoptic view of the origins and economic implications of generalized trust in strangers, see P. Seabright, The Company of Strangers: a Natural History of Economic Life, Princeton 2004. On the centrality of generalized trust to the social capital literature, see Stolle / Hooghe, Conclusion, pp. 232-3.

${ }^{27}$ For cogent criticisms of this gap in social capital theory, see Stolle / Hooghe, Conclusion, pp. 236-7.
} 
(such as gender, ethnicity, religion, or occupation) rather than the transaction in question (property rights, legality, etc.).

It is this uniform trust in institutions as being impartial, fair, and accessible to all members of society which the social capital literature emphasizes as a desirable, long-term outcome. But the immediate priorities of the social capital literature are clubs, associations, guilds, communities - institutions that generate a differential trust, a perception that they are specifically accessible to certain groups (their members), generating a propensity among their members to allow transactions to be mediated by these institutions because they can be trusted to enforce members' particular rights and privileges. The tacit assumption in much of this literature seems to be that encouraging a differential trust in group-specific institutions such as associations will somehow translate into a higher degree of uniform trust in impartial institutions such as markets and governments. ${ }^{28}$ A second purpose of this essay, therefore, is to examine the relationship between a differential and a uniform trust in institutions.

Trust among persons and trust in institutions are interconnected: if you do not trust an institution to enforce contracts you will not trust persons to fulfil their agreements and hence will avoid transacting with them; if you do not trust the persons active in a particular institution (traders in a certain market, judges in a certain law-court, masters in a certain guild) you will avoid transacting via that institution and may refrain from transacting at all. ${ }^{29}$ As will emerge from the empirical findings for pre-industrial Europe, the closely-knit associative networks emphasised in the social capital literature foster a particularized trust in people and a differential trust in institutions. Members of particular guilds and communities were trusted and one was willing to transact with them because of the personal attributes associated with membership in these groups. Guilds and communities themselves were trusted to the extent that they were known to be accessible to individuals with one's own attributes and to enforce the specific rights and privileges associated with those attributes. Generalized trust in strangers and uniform trust in institutions, by contrast, appear to be associated with the emergence of impersonal markets and impartial states - often at the expense of special privileges enjoyed by particular groups. A generalized trust in hitherto unknown transaction partners was manifested when one knew that one's transactions with them would be mediated by an impartial institutional framework that enforced property rights and legal contracts regardless of attributes of the contracting parties. Knowledge of the personal characteristics or group affiliations of transaction partners was unnecessary because one could have confidence that impersonal, efficient and transparent markets were conveying

\footnotetext{
${ }^{28}$ For evidence on modern economies questioning whether social capital goes beyond fostering a differential trust in associative institutions to generating a uniform trust in impartial state institutions, see Stolle / Hooghe, Conclusion, pp. 236-40.

${ }^{29}$ On this, see Dasgupta, Trust, p. 50.
} 
reliable information and that where that information was faulty and a contract was violated, an impartial legal system would punish the offending party.

This discussion has introduced two pairs of concepts that run in parallel:

particularized versus generalized trust in persons, and differential versus uniform trust in institutions. The unspoken assumption of the social capital literature is that the first item in each of these pairs is always complementary with the second. A particularized trust in people who are members of your network brings about a generalized trust in people you do not know, and this makes states and markets work better. A differential trust in institutions (e.g., associations) which enforce your specific rights and transactions somehow gives rise to a uniform trust in governmental and market institutions which will enforce anyone's rights and transactions. Empirical findings for early modern Europe suggest not only that this hypothesis is false, but that its reverse may be true: rather than complements, differential and uniform trust are often substitutes. A final purpose of this essay, therefore, is to explore how economies moved from particularized and differential to generalized and uniform trust, and what role was played in this process by the social capital of trust generated by guilds.

\section{Guilds and Social Capital}

The guild is unquestionably the most important historical institution referred to by political scientists, economists, and policy-makers as an example of 'social capital' and 'trust' in action. Thus, for instance, the influential political scientist and policy advisor Robert Putnam has identified the social capital created by northern Italy's guild tradition as a major determinant of its modern economic success, and argued that lack of this guild tradition condemned the Italian south to centuries of economic and political stagnation. ${ }^{30}$ The development economist Pranab Bardhan has contended that guilds benefited economic growth historically and has urged more studies of how social capital can benefit growth in modern developing economies. ${ }^{31}$ In a 1999 speech to the World Bank, its Chief Economist Joseph Stiglitz listed 'guilds' among those institutions which, by generating social capital, could 'support entrepreneurial efforts' in modern transition economies. ${ }^{32}$

Guilds were widespread in Europe from the medieval period to - in some societies the nineteenth century, and debate still rages about why they existed and the economic impact they exerted. The English-language historiography tends to regard guilds as important only in the medieval period, in the urban economy, and in traditional crafts. This is probably because

\footnotetext{
${ }^{30}$ Putnam et al., Making Democracy Work, pp. 163-85; Putnam, Bowling Alone, pp. 319, 322-3, 325, 346-8.

${ }^{31}$ P. Bardhan, The Nature of Institutional Impediments to Economic Development, Center for International and Development Economics Research Paper C96-066 (March 3, 1996). http://repositories.cdlib.org/iber/cider/C96066, here pp. 6-7.
} 
in the exceptional economies of England and the Low Countries guilds remained restricted to urban crafts, did not spread to export-oriented proto-industries, and from the sixteenth century on were generally weakened and circumvented even in towns, often facing a stark choice between extinction and transformation into much looser and more flexible associations which ultimately came to serve mainly social and cultural purposes. ${ }^{33}$ But in most European economies, as recent research has shown, strong guilds survived long past the medieval period and new ones were formed in the seventeenth, eighteenth, and even nineteenth centuries. ${ }^{34}$ Even in the Low Countries, where guild decline began first, institutional development bifurcated after about 1700, with a continuing decline of guilds in the Southern Netherlands but a resurgence in the United Provinces. ${ }^{35}$ In other regions of Europe, guilds expanded outside the urban craft economy and established themselves in merchant trading and export-oriented proto-industries. ${ }^{36}$ In many central and southern European societies including Germany, Switzerland, Austria, Bohemia, Italy, Spain, Greece, Bulgaria, and Serbia - rural or 'regional' (rural-urban) guilds were established throughout the early modern period. ${ }^{37}$ Guilds' long survival does not mean they were efficient or beneficial, but it does

\footnotetext{
${ }^{32}$ On the relevance of guilds and social capital to modern transition economies, see Stiglitz, New Bridges; Raiser, Informal Institutions, here p. 231.

${ }^{33}$ On the Low Countries, see P. Stabel, Guilds in Late Medieval Flanders: Myths and Realities of Guild Life in an Export-Oriented Environment, in: Journal of Medieval History, 30 (2004), pp. 187-212, here p. 194; J. Mokyr, The Industrial Revolution and the Netherlands: Why Did It Not Happen?, paper presented to the 150th Anniversary Conference Organized by the Royal Dutch Economic Association, 10-11 Dec. 1999, pp. 10-12. On the weakening even of the most powerful guilds in England, the London livery companies, from the sixteenth century on, see J. R. Kellett, The Breakdown of Guild and Corporation Control of the Handicraft and Retail Trades in London, in: Economic History Review, 2nd ser. 10, 1958), pp. 381-94; and the essays in I. A. Gadd / P. Wallis (eds.), Guilds, Society, and Economy in London, 1450-1800, London 2002. For a comparative discussion in the context of protoindustries, see S. Ogilvie, State Corporatism and Proto-Industry: the Württemberg Black Forest, 1580-1797, Cambridge 1997, pp. 412-37.

${ }^{34}$ See the evidence in J. Ehmer, Traditionelles Denken und neue Fragestellungen zur Geschichte von Handwerk und Zunft, in: F. Lenger (ed.), Handwerk, Hausindustrie und die Historische Schule der Nationalökonomie. Wissenschafts- und gewerbegeschichtliche Perspektiven, Bielefeld 1998, pp. 19-77, here pp. 36-7, 54; Ogilvie, State Corporatism, pp. 72-9, 419-37; U. Pfister, Craft Guilds and Proto-Industrialization in Europe, 16th to 18th Centuries, in: S. R. Epstein / H. G. Haupt / C. Poni / H. Soly (eds.), Guilds, Economy and Society, Sevilla 1998, pp. 11-24, here 11-14; and W. Reininghaus, Gewerbe in der frühen Neuzeit, Munich 1990, pp. 61-3, 71-2, 79-80. ${ }^{35}$ On this bifurcation, see Mokyr, Industrial Revolution, pp. 10-12. On the resurgence of guild power in the United Provinces, see S. Bos / P. Lourens / J. Lucassen, Die Zünfte in der niederländischen Republik, in: H.-G. Haupt (ed.), Das Ende der Zünfte. Ein europäischer Vergleich, Göttingen 2002, pp. 127-53, here pp. 128-9; Jan de Vries / A. M. van der Woude, The First Modern Economy: Success, Failure, and Perseverance of the Dutch Economy, 1500-1815, Cambridge 1997, pp. 162-3, 293-4, 340-1, 581-3; U. Pfister, 'The Craft Guild as a Firm' or 'Guilds and Proto-Industrialization in Europe, 16th to 18th Centuries', paper delivered at the conference 'Guilds and NonIndustrial Worlds, Utrecht University, 21-22 January 2000, here pp. 12-13; Jan L. van Zanden, The Rise and Decline of Holland's Economy: Merchant Capitalism and the Labour Market, Manchester, 1993, pp. 127-40. On the restriction of guilds in the Southern Netherlands almost exclusively to urban agglomerations, see $\mathrm{C}$. Lis / H. Soly, Die Zünfte in den österreichischen Niederlanden, in: Haupt, Ende der Zünfte, pp. 155-80, here p. 157; these authors nevertheless differ from Mokyr in arguing (e.g. on pp. 155-6) that Flemish guilds retained economic importance into the eighteenth century.

${ }^{36}$ S. Ogilvie, Social Institutions and Proto-Industrialization, in: S. Ogilvie / M. Cerman (eds.), European ProtoIndustrialization, Cambridge 1996, pp. 23-37, here pp. 30-3; Ogilvie, State Corporatism, pp. 419-31; Pfister, Craft Guilds, pp. 11-14; Pfister, The Craft Guild as a Firm, p. 1.

${ }^{37}$ See the studies surveyed in Ehmer, Traditionelles Denken, pp. 36-7; Ogilvie, Social Institutions, pp. 30-3;

Ogilvie, State Corporatism, pp. 428-31; Pfister, The Craft Guild as a Firm, pp. 5-7.
} 
render them an important object of research for understanding European economic development. ${ }^{38}$

Do guilds actually qualify as social networks that fostered trust along the lines laid out by modern social capital theorists? As already mentioned, James Coleman, the originator of the concept of social capital, defined two criteria that social networks must possess in order to generate social capital: 'closure' and 'multiplex relationships' ${ }^{39}$ Guilds throughout early modern Europe certainly manifested closure through their screening of admission to apprenticeship, journeymanship, and mastership, and their whole or partial exclusion of women, Jews, foreigners, bastards, those whose parents pursued 'defiling' occupations, and members of many other identifiable groups. ${ }^{40}$ Early modern guilds also clearly manifested 'multiplex' relationships. Guild members typically transacted in the same factor and product markets, socialized at their regular taverns, collaborated on political action, and attended each other's weddings and funerals. ${ }^{41}$ Guilds thus displayed to a particularly striking degree the characteristics of closure and multiplex relationships identified by modern theorists as essential for a network to generate significant social capital.

Early modern guilds can also be observed generating all four main manifestations of social capital - shared norms, information flow, punishment of deviants, and political action. Charters, petitions, account-books, and court conflicts are replete with shared norms which guilds explicitly formulated to govern their members' economic, social, and cultural activities. ${ }^{42}$ Guilds appointed officials, inspectors, professional informers, and free-lance spies to inspect workshops, and they held regular assemblies where members were expected to report information relevant to guild interests. ${ }^{43}$ Group sanctions were achieved through guilds' entitlement to punish - either autonomously or through communal or princely courts a vast array of offences, many not explicitly legislated but simply devised at the discretion of local guild officials; guild gossip, rumour and defamation also exerted informal - but often

\footnotetext{
${ }^{38}$ For a detailed discussion of why a widespread and long-lived institution such as the guild cannot (counter to the arguments of some theorists) be assumed to be efficient or beneficial, see S. Ogilvie, Guilds, Efficiency, and Social Capital: Evidence from German Proto-Industry, in: Economic History Review, 52, 2004, pp. 286-333, here esp. pp. 329-31; S. Ogilvie, A Bitter Living: Women, Markets, and Social Capital in Early Modern Germany, Oxford 2003, esp. pp. 340-52.

${ }^{39}$ Coleman, Social Capital, pp. 23-7.

${ }^{40}$ Bos / Lourens / Lucassen, Zünfte, pp. 134-5; J. Forbes, Search, Immigration and the Goldsmiths Company: A Study in the Decline of its Powers, in: I. A. Gadd / P. Wallis (eds.), Guilds, Society, and Economy in London, 1450-1800, London 2002, pp. 115-25, here pp. 120-1; I. A. Gadd / P. Wallis, Introduction, in: Gadd / Wallis, Guilds, pp. 1-14, here p. 7; Ogilvie, State Corporatism, pp. 45-57, 72-9, 127-80; K. Stuart, Defiled Trades and Social Outcasts. Honor and Ritual Pollution in Early Modern Germany, Cambridge 2000, pp. 213-9; Stabel, Guilds, pp. 194-5; Jan Lucassen / Maarten Prak, Guilds and Society in the Dutch Republic (16th-18th Centuries), in: Epstein / Haupt / Poni / Soly (eds.), Guilds, Economy and Society (Sevilla 1998, pp. 63-77, here pp. 66-7. ${ }^{41}$ Bos / Lourens / Lucassen, Zünfte, pp. 133-4; Gadd / Wallis, Introduction, pp. 6, 9-10; Ogilvie, Guilds, Efficiency, and Social Capital, p. 323; Pfister, The Craft Guild as a Firm, pp. 2-3, 17-18; Stabel, Guilds, pp. 189. ${ }^{42}$ Ogilvie, Guilds, Efficiency, and Social Capital, pp. 323-4; Stabel, Guilds, p. 196.

${ }^{43}$ Ogilvie, Guilds, Efficiency, and Social Capital, p. 325; Ogilvie, State Corporatism, pp. 192-203, 310-21; P. Wallis, Controlling Commodities: Search and Reconciliation in the Early Modern Livery Companies, in: Gadd / Wallis, Guilds, pp. 85-100, here p. 91.
} 
effective - pressure on those who violated group norms. ${ }^{44}$ Collective political action was central to most early modern guilds, whose records reveal remarkable expenditures of time and money on lobbying urban and princely councils, bribing officials, and organizing marches, strikes and demonstrations to put pressure on the political decision-making process. $^{45}$

It is not surprising, therefore, that the guild has been identified by modern theorists as the prime historical example of social capital in action. Guilds displayed the characteristics of closure and multiplex relationships which theorists argue are important for a network to generate social capital. And guilds can be observed creating social capital in its four main forms - norms, information, punishment, and collective action. Examining early modern guilds thus has important implications for how we think about social capital and trust more generally.

\section{Guilds and the Use of Trust}

There are three main ways in which guilds are supposed to have used their social capital of trust to benefit the early modern economy. First, guilds are regarded as having generated the trust necessary to solve asymmetries of information between producers, merchants, and consumers concerning product quality, thereby increasing the volume of exchange and enabling industries to expand over larger spatial areas. ${ }^{46}$ Second, guilds are held to have overcome problems of trust in markets for trained labour, thereby increasing the volume of exchange and improving industrial productivity. ${ }^{47}$ Third, guilds are viewed as having created the trust to solve imperfections in markets for technological innovations, creating incentives for innovators to devise new ideas and disseminate their innovations widely. ${ }^{48}$ Examining each of these arguments more closely can tell us something about the strengths and weaknesses of trust in encouraging economic development.

\footnotetext{
${ }^{44}$ Ogilvie, Guilds, Efficiency, and Social Capital, pp. 325-6; Ogilvie, State Corporatism, pp. 321-39; Stabel, Guilds, pp. 192-3.

${ }^{45}$ On the importance early modern guilds attached to lobbying at all levels of the political process, see, for instance, Forbes, Search, p. 117; Gadd / Wallis, Introduction, p. 6; R. F. Homer, The Pewterers Company's Country Searches and the Company's Regulation of Prices, in: Gadd/Wallis, Guilds, pp. 101-13; Ogilvie, Guilds, Efficiency, and Social Capital, pp. 326-9; Ogilvie, State Corporatism, pp. 366-78; Pfister, The Craft Guild as a Firm, pp. 2-3; Stabel, Guilds, pp. 189-91.

${ }^{46}$ B. Gustafsson, The Rise and Economic Behaviour of Medieval Craft Guilds, in: Scandinavian Economic History Review, 35, 1987, pp. 1-40; Pfister, Craft Guilds, pp. 11, 14-18; Pfister, The Craft Guild as a Firm, pp. 2, 5-10; $R$. Reith, Technische Innovation im Handwerk der frühen Neuzeit? Traditionen, Probleme und Perspektiven der Forschung, in: K. H. Kaufhold /W. Reininghaus (eds.), Stadt und Handwerk in Mittelalter und Früher Neuzeit, Cologne etc. 2000, pp. 21-60, here 49-53.

${ }^{47}$ S. R. Epstein, Craft Guilds, Apprenticeship, and Technological Change in Pre-Industrial Europe, in: Journal of Economic History, 58 1998, pp. 684-713, here pp. 688-93; Pfister, Craft Guilds, pp. 14, 18; Pfister, The Craft Guild as a Firm, p. 2.
} 


\subsection{Guilds, Trust and Quality}

The first way in which guilds are supposed to have used their social capital to benefit the economy was by creating trust about product quality. In the pre-industrial economy, it is argued, information asymmetries between producers and consumers were very high - much higher than in modern economies. Lack of trust among consumers and merchants toward producers of craft wares is supposed to have been so great that it significantly reduced their willingness to make purchases. This in turn harmed the economy by diminishing the overall volume of exchange and reducing gains from trade. ${ }^{49}$

Guilds, it is claimed, created the trust to overcome this market failure. They did so by regulating raw materials, production processes, apprenticeship, journeymanship, mastership examinations, trademarks, and output quality, and (in dispersed rural proto-industries) by contracting collectively with merchants. ${ }^{50}$ That is, guilds enforced rules which created a 'particularized' trust in guild members, giving consumers and merchants the confidence to enter into transactions with them. On the face of it, this seems a perfect example of social capital theory, whereby a particularized trust in persons of known attributes (guild masters) and a differential trust in an institution which enforced particular producers' privileges (the guild) solved a market failure, thereby encouraging uniform trust in another institution (the market) and even gradually fostering a generalized trust in strangers.

But is this really what guilds did? When we look more closely, some cracks begin to appear in this optimistic analysis. A first problem relates to the evidence usually adduced in its support, which is mainly literary or legal. To establish that guild-specific trust was economically necessary - i.e., that there really was a serious failure in markets for product quality - enthusiasts for guilds point out frequent references to poor craftsmanship in contemporary plays and poems, arguing that these demonstrate that deceit and fraud about product quality were serious and widespread problems in the pre-industrial economy. ${ }^{51}$ It must be recognized, however, that literature is written for particular purposes, and serves explicitly rhetorical and often normative ends. This makes it an unreliable guide to what was actually happening. Thus, for instance, poor craftsmanship was generally associated with wicked characters in morality plays, and served the purpose of making evil comprehensible in terms of everyday life; such allusions do not convey information about how widespread such wickedness was. Even if poor craftsmanship was widespread, frequent literary allusions to it

\footnotetext{
${ }^{48}$ Epstein, Craft Guilds, pp. 693-705; Pfister, The Craft Guild as a Firm, p. 2; Reith, Technische Innovation, pp. 45-8.

${ }^{49}$ Gustafsson, Rise, pp. 5, 13-24; Pfister, Craft Guilds, pp. 14-16; Pfister, The Craft Guild as a Firm, pp. 5-10.

${ }^{50}$ Lis / Soly, Zünfte, pp. 165-6; Gustafsson, Rise, pp. 5, 13-24; Pfister, Craft Guilds, pp. 14-16; Pfister, The Craft Guild as a Firm, pp. 5-10; Stabel, Guilds, p. 206.

${ }^{51}$ Gustafsson, Rise, pp. 3, 13-15, 23; Pfister, Craft Guilds, pp. 16-17.
} 
may as easily have arisen from guilds' failure to control quality as from their desire or effectiveness in doing so.

Nor is the second main source of evidence for guilds' importance in creating trust about product quality much more reliable. Legislation is the mainstay of the theoretical literature on pre-industrial guilds. ${ }^{52}$ But it is a deeply questionable source of evidence about what guilds actually did. ${ }^{53}$ For one thing, legislation resembles literature in serving purposes that are not apparent on the surface - that is, in having a hidden agenda. Second, early modern legislation was often not enforced. And third, the claims made by theorists about guild legislation are in many cases inaccurate.

Guild statutes certainly claimed that only guild members could be trusted to produce wares of an acceptable quality and that the guild was the only institution that could be trusted to enforce quality standards. But we must read such claims critically and consider the interests they served. Guild charters were often influenced or actually drafted by guild members themselves: much early modern urban and princely legislation had its origins in petitions submitted by concerned interest groups, and guild statutes were a prime example of this pattern. ${ }^{54}$ Ensuring a high quality of wares sounds like an indisputable 'good' for society at large, although we will shortly examine reasons why enforcing high quality at all costs is not necessarily economically beneficial. Because maintaining product quality was viewed as unquestionably 'good', it provided a nearly indisputable rhetorical basis for justifying restrictions - such as entry barriers, output quotas, and price controls - that served more narrow group interests and would otherwise have aroused social and political opposition.

Furthermore, legislation is one thing and enforcement quite another. The statute books of early modern European towns and princes contained many regulations that were never implemented at all. ${ }^{55}$ Other regulations on the statute-books enjoyed some enforcement, but nevertheless were widely evaded, creating black markets or 'informal sectors'. In these cases, regulations did have an effect on the activities of individuals and the functioning of the wider economy, but not the one intended by princes, city governments, or guilds when they framed the regulations. ${ }^{56}$ Finally, there were some regulations that were enforced - and left traces in non-legislative sources such as guild accounts or community court minutes - but were devised at the discretion of local guild officials and did not actually appear in formal

\footnotetext{
${ }^{52}$ Gustafsson, Rise, pp. 9, 13.

${ }^{53}$ On this, see e.g. Ehmer, Traditionelles Denken, 29, 40; H. Bräuer, Entwicklungstendenzen und Perspektiven der Erforschung sächsischer Zunfthandwerksgeschichte, in: Jahrbuch für Regionalgeschichte und Landeskunde, 19, 1993/4), pp. 5-65, here p. 37; Wallis, Controlling Commodities, p. 86; Stabel, Guilds, pp. 187, 197.

${ }^{54}$ Ehmer, Traditionelles Denken, p. 39; Ogilvie, State Corporatism, pp. 89-95.

${ }^{55}$ On this see, for instance, J. Schlumbohm, Gesetze, die nicht durchgesetzt werden - ein Strukturmerkmal des frühneuzeitlichen Staates?, in: Geschichte und Gesellschaft, 23, 1997, pp. 647-63; Pfister, The Craft Guild as a Firm, pp. 4-5.

${ }^{56}$ For early examples of evasion of even the most powerful London guilds, see Homer, The Pewterers Company's Country Searches, pp. 106-7; Forbes, Search, pp. 117-19.
} 
statutes. The general lesson is that although guild legislation can provide a guide to how guilds ought to have functioned, it must be checked against alternative sources of evidence in order to establish how they actually did function - whether in creating trust about product quality or any other matter.

Finally, even if legislation had been perfectly enforced, a number of the claims guild theorists have made about its content are quite inaccurate. Thus, for instance, the most influential proponent of the view that guilds were beneficial because they guaranteed quality states that 'the majority of the guild statutes are concerned precisely with demands for a sufficiently high quality of product' and that guilds imposed 'exceedingly harsh sanctions for violating the quality regulations' ${ }^{57}$ But this is simply not the case. The only quantitative analysis of guild charters of which I am aware is that of the ordinances for the powerful weavers' guilds which regulated the worsted proto-industry of the southern German state of Württemberg from the sixteenth to the nineteenth century. In the four surviving ordinances for these guilds, only a minority of articles - in one ordinance, as few as 8 per cent - were even remotely concerned with quality control. ${ }^{58}$ Moreover, the quality standards laid down were quite minimal. Here, as in many early modern textile industries, guild statutes merely set standard legal dimensions for wares (something easily checked by merchants and customers), but did not go in detail into quality issues involving matters that might have involved true information asymmetries between producers and customers. Nor were sanctions always 'exceedingly harsh'. The Württemberg worsted guilds imposed very light penalties on quality offences, fines that were significantly lower than those for offences against other guild norms; severe penalties such as destruction of wares, confiscation, imprisonment, or ejection from the guild never came into question. ${ }^{59}$ The most powerful guilds in England, the livery companies of early modern London, also imposed very lenient penalties - apologies, fines, promises of reformation - 'even in quite serious matters such as assaults [on guild quality inspectors] or the deliberate falsification of goods ${ }^{60}$ The claim by guild theorists that guild statutes placed heavy emphasis on quality maintenance and penalized quality offences severely thus does not hold up to empirical scrutiny.

Equivalent quantitative analyses of the statutes of many more guilds would be necessary before one could place reliance on the claim that most guilds even in principle made it a priority to create trust between producers and consumers about product quality. Analysis of more and better sources - guild accounts, court records - would be necessary to establish that guilds actually succeeded in creating such trust. Indirect evidence comparing

\footnotetext{
${ }^{57}$ Gustafsson, Rise, pp. 9, 13.

${ }^{58}$ Ogilvie, State Corporatism, pp. 345-8.

${ }^{59}$ Ogilvie, State Corporatism, pp. 348-52.

${ }^{60}$ Wallis, Controlling Commodities, pp. 88-92.
} 
quality outcomes in guilded and unguilded industries can help us address this question, but before we examine this evidence there is a fundamental theoretical problem to consider.

The claim that guilds were beneficial because they created trust about quality often takes for granted that what consumers wanted, and what was best for the economy, was a high absolute quality. Thus demand is supposed to have been low because consumers did not trust craftsmen to refrain from exploiting information advantages by producing low-quality products. A guild, by contrast, could create such consumer confidence by imposing rules ensuring that all craftsmen produced at or above a defined quality. This created particularized trust in a specific group of transaction partners - a belief that one could feel confidence in entering into a transaction with any person who was a member of the relevant guild, because its rules required him to produce high-quality goods. ${ }^{61}$ It also created differential trust in a particular institution - the guild - as the guarantor of these rules.

But this argument rests on a basic confusion. The problem of 'quality' under asymmetric information relates to the variance, not the mean. The market failure is solved by guaranteeing not high quality but standard quality. This standard can be low, as long as the customer knows what it is. ${ }^{62}$ To rescue the argument that guilds were beneficial because they created trust about product quality, therefore, we must revise it: guilds must have been an efficient institution for guaranteeing a standard - not a high - quality level.

In principle, guilds might indeed have constituted such an institution. ${ }^{63}$ But they had a serious weakness in doing so. Most guilds justified a whole array of their most important regulations - entry barriers, output quotas, and price controls - by claiming that these were essential for ensuring high quality. Many also profited financially from setting inappropriately high quality standards. Thus, for instance, the London pewterers' guild levied quality fines on products from provincial workshops 'on the flimsiest pretext', not because 'the London company was driven by altruism to protect the populace at large from dubious goods' but because of 'the profit received from fines and from the sale of seized metal', which it split with the Crown in return for enforcement of its charter. ${ }^{64}$ Incentives such as these could lead guilds to impose inappropriately high quality standards. As we shall see shortly, in many early modern industries, a lower (but standardized) quality in combination with a lower price would have better addressed customer demand. But standard quality would not have functioned nearly so well as high quality in justifying long apprenticeship and journeymanship and bans on price competition, which ensured important streams of rents for

\footnotetext{
${ }^{61}$ Gustafsson, Rise, pp. 3, 13-15, 23; Pfister, Craft Guilds, pp. 16-17; Stabel, Guilds, p. 206.

${ }^{62}$ G. A. Akerlof, The Market for 'Lemons': Quality Uncertainty and the Market Mechanism, in: Quarterly Journal of Economics, 84, 1970, pp. 488-500.

${ }^{63}$ As claimed, for instance, by Stabel, Guilds, p. 206.

${ }^{64}$ Homer, The Pewterers Company's Country Searches, p. 107. Also on the financial incentives behind guilds quality controls, see Forbes, Search, p. 118.
} 
guild masters but would - without the excuse of quality control - have risked attracting social and political opposition.

Furthermore, for either maximizing quality or minimizing variance, there is a cost in terms of innovativeness, flexibility, and the ability to adjust to changing fashions and consumer preferences. ${ }^{65}$ A single, monopolistic entity such as a guild might have been better placed than a variegated range of individual producers to guarantee the best possible quality or even a single, standard quality. But precisely these characteristics made a guild less able, and probably also less willing, to undertake the market research and the flexible response to changes in demand necessary to deliver the combinations of quality and price desired by a varied and changing population of consumers. ${ }^{66}$ These issues were recognized by contemporaries such as the seventeenth-century English economist and merchant Josiah Child:

All our laws that oblige our people to the making of strong, substantial, and, as we call it, loyal cloth, of a certain length, breadth, and weight, if they were duly put into execution would, in my opinion, do more hurt than good, because the humours and fashions of the world change, and at some times, in some places (as now in most), slight, cheap, light cloth will sell more plentifully and better than that which is heavier, stronger, and truer wrought; and if we intend to have the trade of the world we must imitate the Dutch, who make the worst as well as the best of all manufactures, that we may be in a capacity of serving all markets and all humours. I conclude all our laws limiting the number of looms, numbers or kind of servants, or times of working, to be certainly prejudicial to the clothing trade of the kingdom in general. ${ }^{67}$

Child was far from being the only contemporary to express scepticism about whether guild laws about quality were beneficial. ${ }^{68}$ In many early modern industries, guild quality inspections were viewed as inadequate. Guild members who committed quality offences suffered minor sanctions in the short term and none in the long term. ${ }^{69}$ Community officials and state bureaucrats incessantly exhorted individual guild members and guild inspectors to do their jobs better. ${ }^{70}$ Merchants opted sooner or later to ignore guild inspections and set up

\footnotetext{
${ }^{65}$ For the general argument that less trust and cooperation may sometimes be beneficial because of the positive influence of a certain dose of competition, see Gambetta, Can We Trust Trust?, p. 214.

${ }^{66}$ As argued for the successful West Riding woollen and worsted industries in H. Heaton, The Yorkshire Woollen and Worsted Industries from the Earliest Times up to the Industrial Revolution, Oxford 1965, pp. 417-18.

${ }^{67}$ Quoted in E. Lipson, The History of the Woollen and Worsted Industries, London, 1965; 1st edn 1921), p. 118.

${ }^{68}$ Gustafsson, Rise, p. 22.

${ }^{69}$ Wallis, Controlling Commodities, p. 96; Ogilvie, State Corporatism, pp. 348-52.

${ }^{70}$ R. S. DuPlessis, One Theory, Two Draperies, Three Provinces, and a Multitude of Fabrics: the New Drapery of French Flanders, Hainaut, and the Tournaisis, c. 1500-c. 1800, in: N. B. Harte (ed.), The New Draperies in the Low Countries and England, Oxford 1997, pp. 129-72, here p. 159; Heaton, Yorkshire, p. 58; Homer, The Pewterers Company's Country Searches, pp. 105-6; Forbes, Search, pp. 117-8; Ogilvie, State Corporatism, pp. 348-52; Wallis, Controlling Commodities, p. 90.
} 
their own independent inspection arrangements. Precisely because guilds could not (or would not) themselves control quality, independent inspections by merchants, town officials, and state inspectors were necessary to enhance them, and in the most dynamic industries replaced them. ${ }^{71}$ Merchants and customers were eager to purchase wares from non-guild producers particularly peasants and women - precisely because the wares they produced had the same quality as those that passed guild inspections, but at a lower price. ${ }^{72}$

There are good theoretical reasons why a closed social network may tend to give rise to just such an outcome - i.e., may not have the incentive to use its social capital of 'trust' for socially beneficial ends. ${ }^{73}$ Once a guild possessed a state charter that endowed its members with the monopolistic entitlement to practise a particular occupation, there was often little outside pressure that could be placed on it to improve its performance - whether with regard to product quality or to any other aspect of its members' behaviour. ${ }^{74}$ As is clearly recognized in modern economies, self-regulating professional associations suffer from disincentives to offend or penalize their members, and must be closely monitored by governments and consumers. Certainly, early modern guild inspectors often lacked the incentive to develop the skills and deploy the effort necessary to detect low-quality work beyond superficial features (such as size) which, as contemporaries pointed out, were readily apparent to potential customers anyway. ${ }^{75}$

Furthermore, even if guild inspectors detected low-quality work, they had incentives to turn a blind eye, punish it leniently, or make excuses for a fellow guild master. Preindustrial European documentary sources are replete with cases in which customers complained about wares but guild officials were so reluctant to proceed that the customer had to appeal to state authorities to have the complaint taken at all seriously. Thus, for instance, in 1793 Anna Maria Schultheiß, the mayor's wife in the small Württemberg town of Wildberg, complained to the foremen of the linen-weavers' guild that a length of linen she had just bought from Salomo Roller was of poor quality but the faults had been hidden through

\footnotetext{
${ }^{71}$ On quality regulation by municipal and princely authorities in Montpellier in the 1350 s, see K. L. Reyerson, Commercial Fraud in the Middle Ages: the Case of the Dissembling Pepperer, in: Journal of Modern History, 8 , 1982, pp. 63-74, here pp. 63, 67. For examples of early modern industries in which inadequate guild quality controls were replaced by merchant, municipal, or state inspections, see K. Finkenwirth, Urkundliche Geschichte der Gera-Greizer Wollwarenindustrie von 1572 bis zur Neuzeit (Weida, 1910), pp. 41, 62, 66; Forbes, Search, pp. 122-3; Heaton, Yorkshire, pp. 416-17; Ogilvie, State Corporatism, pp. 348-52; Ogilvie, Guilds, Efficiency, and Social Capital, pp. 294-5, 300-01; Pfister, The Craft Guild as a Firm, p. 9; J. Torras, The Old and the New. Marketing Networks and Textile Growth in Eighteenth-Century Spain, in: M. Berg (ed.), Markets and Manufacture in Early Industrial Europe, London, 1991, pp. 93-113, here p. 105; J. Torras, From Craft to Class: the Changing Organisation of Cloth Manufacturing in a Catalan Town in T. Safley / L. Rosenband (eds.), The Workplace before the Factory: Artisans and Proletarians, 1500-1800, Ithaca 1993, pp. 165-79, here pp. 173-5.

${ }^{72}$ DuPlessis, One Theory, p. 153.

${ }^{73}$ For an illuminating example of how the mafia in southern Italy used its particularist and differential trust to create quality guarantees, but did not thereby serve socially beneficial ends, see Gambetta, Mafia, pp. 171-3.

${ }^{74}$ Homer, The Pewterers Company's Country Searches, pp. 103-5; Ogilvie, State Corporatism, pp. 348-52; Wallis, Controlling Commodities, pp. 92-6.

${ }^{75}$ W. Troeltsch, Die Calwer Zeughandlungskompagnie und ihre Arbeiter, Jena 1897, p. 120; Wallis, Controlling Commodities, pp. 90-5; Ogilvie, State Corporatism, p. 350.
} 
fulling. The guild foremen were reluctant to take action, not only letting the cloth pass the guild inspection but also accepting it as a master-piece and admitting Roller to mastership. Their only response to Anna Maria's complaint was to say that she need not pay Roller, 'leaving the payment of a weaving-wage to her free will'. Anna Maria was only able to get the matter taken seriously by prevailing on a male neighbour to inquire at the Rüggericht - an annual community assembly of male citizens in front of the princely district governor - why, despite this poor-quality master-piece, Roller 'had nevertheless been admitted to mastership'. Even then, the court decided that 'because one was already convinced of Roller's skill in the profession from other information received, he could not be rejected' ${ }^{76}$ Thus in a guilded economy a dissatisfied customer had to take her case to the community or state authorities anyway, and might only succeed in doing so if she was the mayor's wife. Even then, the influence of guild masters could be such as to preclude any penalty against the fraudulent master other than the customer's not having to pay for faulty wares - precisely the same outcome as in an unguilded situation. Anna Maria could not even change suppliers since guilded weavers (including the one who had cheated her) were the only legal producers and sellers of linen and only a few were allowed to do business in each community: thus in 1793 the fraudulent (or at least unskilled) Salomo Roller was one of only two linen masters in Wildberg.

For these reasons, it is not clear that consumers were worse off when guilds were weak or absent. In weakly guilded industries, a dissatisfied customer had to take his complaint to the state - a Justice of the Peace, a community council sitting, a state court. ${ }^{77}$ Thus in early modern England, 'the maker or seller of a substandard ware was liable to forfeiture of the ware or its value, which was recoverable by court action, one half of the proceeds going to the Crown and the other half to the person who sued' ${ }^{78}$ Examination of the tailoring trade in early modern London 'suggests that many customers were prepared to sue their suppliers in the city courts'. ${ }^{79}$ But in strongly guilded Württemberg, Anna Maria Schultheiß had to take her case beyond the guild to the state authorities anyway, even to obtain a hearing. In an economy with weak guilds or none, a dissatisfied customer might even gain fairer justice than in a guilded one, since the state would be less subject to guild pressure. That is, in the absence of organized producer interest groups, the state had a greater capacity to dispense impartial justice and attract uniform rather than differential trust from its citizens.

\footnotetext{
${ }^{76}$ Hauptstaatsarchiv Stuttgart (hereafter HSAS) A573 Bü. 100, Ruggerichts Rezessbuch, 1793, fol. 22r-v: 'die bezahlung eines Weberlohns des Hrn burgermeisters Schultheiß Frau freyem willen überlaßen'; 'dennoch seye solcher als ein Meister aufgenommen worden'; 'man von deßen Geschiklichkeit in der Profession aus andern Nachrichten schon überzeugt worden, nicht abgewiesen werden können'.

${ }^{77}$ De Vries / Van der Woude, First Modern Economy, p. 582; Heaton, Yorkshire, pp. 124-32, 224-5, 241-2, 253, 297-300, 379-80, 386-7, 405-18; Wallis, Controlling Commodities, pp. 90-1.

${ }^{78}$ Forbes, Search, p. 119.

${ }^{79}$ M. Davies, Governors and Governed: the Practice of Power in the Merchant Taylors Company in the Fifteenth Century, in: Gadd / Wallis, Guilds, pp. 67-83, here p. 79.
} 
Even in the comparatively weakly guilded Netherlands, 'for consumers, the guilds were no unalloyed benefit', but at least 'the town governments could regulate [the guilds] to serve consumer interests by fixing prices and demanding quality guarantees' ${ }^{80}$

In cases where the state failed to dispense uniform justice, the disgruntled customer in a weakly guilded economy could turn to another 'uniform' institution: she could take her custom elsewhere in an open market that did not grant 'differential' privileges to guild producers. This option was closed to her in a strongly guilded economy where she was obliged to go on patronizing local guild masters whose legal monopoly not only limited their numbers (and hence the customer's choice) but also protected their low-quality output from competition. Thus in Wiltshire or Yorkshire, when a weaver produced shoddy cloth, customers, factors, and merchants could simply shift their custom to another of the large and competitive population of dispersed rural weavers, since no guild privileges compelled customers to go on patronizing a small circle of established masters irrespective of the quality of their wares. ${ }^{81}$ In early modern London, 'those customers who were not satisfied ... could simply take their business elsewhere ... customers were themselves far from naïve' ${ }^{82}$ Precisely the lack of guild restrictions on customers' capacity to shun unskilled or fraudulent producers led a craftsman such as the seventeenth-century London turner Nehemiah Wallington to perceive 'that any frauds he perpetrated, no matter how accidentally, would rebound severely' - not because he would be punished by his guild, but because his customers would turn elsewhere. ${ }^{83}$ In short, the lack of guild restrictions preventing the customer from taking her custom elsewhere on an open market led to a growing recognition that, in the words of one eighteenth-century Yorkshire clothier, 'The interest of the seller is sufficient security to the buyer for fair dealing, ${ }^{84}$

These examples from weakly guilded industries in early modern Europe suggest that in the absence of guild privileges, both the state and the market were more likely to function impartially, helping to create a 'uniform' trust in institutions that would enforce the contracts of anyone rather than a 'differential' trust in institutions that only enforced the rights of guild members. This uniform trust in impartial institutions was in turn more likely to generate a 'generalized' trust in strangers which could gradually displace the 'particularized' trust in persons of known attributes or group affiliations.

Empirical comparisons across different European industries appear to confirm that guilds were not necessarily efficient institutions for creating trust between producers and

\footnotetext{
${ }^{80}$ De Vries / Van der Woude, First Modern Economy, p. 582.

${ }^{81}$ Heaton, Yorkshire, pp. 124-32, 224-5, 241-2, 253, 297-300, 379-80, 386-7, 405-18; A. J. Randall, Before the Luddites: Custom, Community and Machinery in the English Woollen Industry, 1776-1809, Cambridge 1991, pp. $35-8$.

${ }^{82}$ Davies, Practice of Power, p. 79.

${ }^{83}$ Wallis, Controlling Commodities, p. 96.

${ }^{84}$ Lipson, History, p. 120.
} 
consumers about product quality. Those industries that were most successful at attracting and satisfying customers - the best measure of consumer 'trust' in product quality available to modern economic historians - were not the ones with the strongest (or necessarily any) guilds. From the early sixteenth century onward, the same industry was often strongly guilded in one part of Europe, weakly guilded in another, and guild-free in a third. Thus rural linen weaving, worsted weaving, cotton weaving, scythe making, lace making, and the making of small iron goods were guilded in many parts of Germany, Austria, Italy, Spain, Bohemia, Serbia, Bulgaria, and Greece, but weakly guilded in Scotland, Switzerland, and Ireland, and wholly unguilded in most parts of England and the Low Countries. ${ }^{85}$ Yet indisputably the most successful industries in Europe were those in the Low Countries and England, where guild restrictions were totally absent from many lively rural industrial regions and in the course of the sixteenth and seventeenth centuries lost most of their powers in towns. ${ }^{86}$

Even in the medieval period there were cities such as Douai which developed successful, high-quality export industries without quality enforcement through guilds. ${ }^{87}$ Shortly after 1500, the Flemish village of Hondschoote developed the first successful New Draperies export industry without imposing any guild quality controls until the late sixteenth century, 'after it had passed its apogee ${ }^{88}$ By the mid-sixteenth century, even the powerful London companies are described as being 'not overly concerned with issues of quality control; the nature of goods remained largely an issue for customers and retailers to negotiate in the marketplace' ${ }^{89}$ In the eighteenth century, the West Riding of Yorkshire developed the most successful worsted industry in Europe by producing 'cheap and nasty' cloths subject to no quality controls by guilds: quality was monitored by merchants at point of sale. ${ }^{90}$ By 1753 it was possible for an English Parliamentary Committee to state categorically that guilds' powers to search craft workshops to enforce quality regulations were 'illegal and contrary to

\footnotetext{
${ }^{85}$ Ogilvie, State Corporatism, pp. 428-31; Ogilvie, Social Institutions, pp. 30-3; Pfister, Craft Guilds, p. 21; Pfister, The Craft Guild as a Firm, pp. 16-17.

${ }^{86}$ For a detailed analysis of these issues across different European worsted industries, see Ogilvie, Guilds, Efficiency, and Social Capital, pp. 291-301. For discussions of the waning powers of London guilds to penalize quality infractions, see Wallis, Controlling Commodities, pp. 89-90; Homer, The Pewterers Company's Country Searches, p. 107.

${ }^{87}$ M. C. Howell, Achieving the Guild Effect without Guilds: Crafts and Craftsmen in Late Medieval Douai, in: $P$. Lambrechts / J. P. Sosson (eds.), Les métiers au Moyen Âge, Louvain-la-Neuve 1994, pp. 109-28.

${ }^{88}$ J. H. Munro, The Origin of the English 'New Draperies': the Resurrection of an Old Flemish Industry, 12701570, in: Harte, New Draperies, pp. 35-128, here p. 87; J. Craeybeckx, Les industries dexportation dans les villes flamandes au XVIIe siècle au début du XVIIIe siècle, in: M. Spallanzani (ed.), Produzione, commercio, e consumo dei panni di lana nei secoli XII-XVIII, Florence 1976, pp. 475-510, here pp. 23, 40.

${ }^{89}$ Gadd / Wallis, Introduction, p. 9. On the gradual collapse of quality controls by even the most powerful early modern London companies, see Homer, The Pewterers Company's Country Searches, p. 107; Wallis, Controlling Commodities, pp. 89-90.

${ }^{90}$ Heaton, Yorkshire, pp. 379-82, 386-8, 418-37; P. Hudson, The Genesis of Industrial Capital: a Study of the West Riding Wool Textile Industry c. 1750-1850, Cambridge 1986, pp. 36, 156-7; P. Hudson, Capital and Credit in the West Riding Wool Textile Industry, c. 1750-1850, in: P. Hudson (ed.), Regions and Industries. A Perspective on the Industrial Revolution in Britain, Cambridge 1989, pp. 69-102, here p. 69-72; Lipson, History, pp. 80-1, 119; R. G. Wilson, The supremacy of the Yorkshire cloth industry in the eighteenth century, in: $N$. $B$. Harte / K. G. Ponting (eds.), Textile History and Economic History: Essays in Honour of Miss Julia de Lacy Mann, Manchester 1973, pp. 225-46, here pp. 244-5.
} 
the Liberty of the subject; tending to a Monopoly; discouraging the Manufacture and destroying the Trade of the Kingdom, ${ }^{91}$ Yet for long after this date, guild quality inspections remained powerful in many continental European crafts and proto-industries. ${ }^{92}$

Judging by the eagerness of customers across the world to buy the innovative and low-cost Flemish, Dutch, and English worsteds, woollens, linens, and (ultimately) cottons, the largely unguilded industries of these economies were outstandingly good at creating trust between producers and consumers. But the trust they created was not a 'particularized' trust in guild members or the 'differential' trust in guilds as institutions enforcing the privileges of guild members and the rights of those consumers that complied with guild monopsonies. Rather, it was a 'generalized' trust in unknown transaction partners mediated by a 'uniform' trust in an impartial institutional framework that enforced contracts regardless of personal attributes of the contracting parties. Industries in these economies were exceptionally good at creating trust among consumers that markets were conveying reasonably accurate signals about product quality and that the state would punish breaches of contract - in short, a confidence in buying things anonymously from people whose personal attributes and guild affiliations one did not know, using institutional mechanisms that were accessible to anyone. This suggests that these economies and their industries flourished not because they encouraged the particularized and differential trust fostered by guilds, but because they gradually discouraged and replaced it with the generalized and uniform trust generated by states and markets.

\subsection{Guilds, Trust and Training}

The market for human capital is a second arena in which guilds are supposed to have used their social capital to create trust which benefited the entire economy. According to this view, pre-industrial crafts were highly skilled activities that required extensive formal training. But training markets are supposed to have functioned poorly because information asymmetries and fear of opportunistic behaviour created a lack of trust between trainers and trainees. Consequently, it is claimed, good masters found it impossible to identify good potential apprentices and journeymen, and vice versa. This is held to have given rise to an unwillingness on both sides to enter into training contracts, leading to under-investment in training, scarcity of skilled labour, lower productivity, and foregone output. ${ }^{93}$

Guilds are supposed to have generated the trust that solved these market imperfections. They did so through fostering four shared norms. First, they imposed

\footnotetext{
${ }^{91}$ Quoted in Forbes, Search, p. 120.

${ }^{92}$ See, for instance, Ogilvie, State Corporatism, pp. 343-57;
} 
admissions requirements, thereby enabling masters to trust applicants to apprenticeship positions. Guilds usually imposed prerequisites on anyone wishing to become an apprentice, requiring him to be (for example) male, son of an existing guild master, son of a local community citizen, member of the same religious confession as existing guild members, certifiably legitimate offspring of married parents (sometimes even of legitimately married grandparents or great-grandparents), able to pay high apprenticeship fees, or non-member of particular 'defiling' groups (Jews, Roma, knackers, executioners, etc.). The function of these admissions requirements, according to modern theorists, was to act as a signal that the apprentice and master belonged to the same social network. Shared network membership meant a master could trust that an apprentice would behave well during training and vice versa. Second, guilds promulgated regulations penalizing opportunistic behaviour by masters and apprentices once the training contract had been signed, thereby further ensuring that potential trainers and trainees could trust one another. Third, guilds issued apprenticeship certificates with the purpose of enabling masters to identify good journeymen - that is, to trust applicants for employment because of their group affiliation with the guild. Finally, guilds imposed mastership admissions requirements with the aim of enabling apprentices to identify skilled trainers - that is, they created a particularized trust in those employers who could demonstrate that they had the appropriate group affiliation and a differential trust in the guild as an institution which would enforce training contracts between guild members. ${ }^{94}$

Once again, legislation is the empirical mainstay of the view that guilds created trust that made markets in human capital and skilled labour work better. Guild legislation always made elaborate provisions for apprenticeship, journeymanship, masterpiece examinations, and mastership admission requirements. But for the reasons discussed in the preceding section, we must read guild statutes critically with an eye to the interests they served. Like product quality, labour skills could be portrayed as unquestionably a good thing, and hence could be used to justify regulations that would otherwise evoke social opposition. Moreover, like guild statutes governing product quality, those governing apprenticeship, journeymanship and mastership were not invariably implemented, were evaded (resulting in black market activity), or were interpreted in ways that benefited particular interests.

Quite apart from the question whether legislation can be trusted to reflect enforcement, apprenticeship, journeymanship, and mastership requirements potentially served two different purposes. One was to create the particularized trust that would encourage masters to offer and apprentices to undertake skilled training because they could have confidence that each other's characteristics had been screened by the guild. The other was to

\footnotetext{
${ }^{93}$ Epstein, Craft Guilds, pp. 687-93; Gustafsson, Rise, p. 21; Pfister, Craft Guilds, p. 18; Pfister, The Craft Guild
} as a Firm, pp. 10-11. 
enable established producers to restrict entry to the industry, thereby protecting themselves from competition..$^{95}$ The particularized trust in guild masters, journeymen and apprentices thus had the potential to be used to encourage human capital investments by insiders or abused to exclude outsiders.

To find out which predominated, we need independent evidence bearing on the following four questions: First, was extensive formal training necessary in all activities that were guilded? Second, were guilds the best way to ensure such training? Third, how did guilds manage the trade-off between the training and exclusion functions of their regulations? And fourth, were industries with strong guild structures also ones that achieved optimal levels of training? When such evidence is considered, it reveals a more complicated picture than the optimistic view that guild rules created the trust that encouraged optimal human capital investment.

First, how important was formal training to early modern economies? Contrary to the claims of early modern guilds themselves and enthusiasts for guilds among modern social scientists, there were many economic activities in pre-industrial Europe that did not require very high levels of skill, hence did not require prolonged formal training, and yet were guilded. ${ }^{96}$ This was certainly true of the wool textile industry, especially after the spread of the New Draperies from the later sixteenth century. It also applied to the linen industry, which expanded rapidly from the seventeenth century on and accelerated in the eighteenth century on a very low skill basis: although linen production was unguilded in most parts of northwest Europe, it remained guilded into the later eighteenth century in many parts of central, eastern and southern Europe. As a general rule, the most flourishing textile industries in early modern Europe produced cheap cloths that required little skill to make, but precisely for that reason were affordable by a much wider mass market than the expensive old-style woollen broadcloths or silk-based fabrics. Worsted and linen weaving were easily learned contemporaries often remarked that they could be grasped in a few weeks or months. Thus they could be successfully practised without formal guild training, and yet they were often guilded. Indeed, contemporaries remarked of many guilded activities - not just cheap textile production - either that they needed no formal training at all, or that they required many fewer years of training that guild rules demanded. It seems unlikely that crafts requiring high levels of skilled training represented a very large proportion of overall industrial activity,

\footnotetext{
${ }^{94}$ Epstein, Craft Guilds, pp. 687-93; Gustafsson, Rise, p. 21; Lis / Soly, Zünfte, pp. 165-6; Pfister, Craft Guilds, p. 18; Pfister, The Craft Guild as a Firm, pp. 10-11.

${ }^{95}$ On the exclusionary functions of guilds, see $J$. Rule. The PRoperty of Skill in the Period of Manufacture, in: $P$. Joyce (ed.), The Historical Meanings of Work, Cambridge 1987, pp. 99-118, here p. 107; D. M. Hafter, Women in the Underground Business of Eighteenth-Century Lyon, in: Enterprise and Society, 2 (2001), pp. 11-40, here pp. 14-18, 27-32; P. Lourens / J. Lucassen, Gilden und Wanderung: die Niederlände, in: K. Schulz / E. Müller-Luckner (eds.), Handwerk in Europa vom Spätmittelalter bis zur Frühen Neuzeit, Munich 1999, pp. 65-79, here pp. 66-7, 75-9; Gadd / Wallis, Introduction, p. 7.

${ }^{96}$ As acknowledged, e.g., in Pfister, The Craft Guild as a Firm, p. 13.
} 
since textiles were by far the most important industrial sector, and a large and growing share of textile production was in the low-skilled worsted, light woollen, linen, and cotton branches. This suggests that any harm done by lack of trust between trainers and trainees may simply not have affected large sectors of the early modern economy.

Indisputably, however, there were industrial activities in early modern Europe that did require formal training. ${ }^{97}$ The second question we must address, therefore, is whether guilds were the best institution for ensuring such training. On the one hand there is evidence of a proliferation of private apprenticeship contracts in economies as distant and dissimilar as seventeenth-century England and nineteenth-century Russia, indicating that guilds were not necessary to create the trust to induce masters and apprentices to enter into training agreements. ${ }^{98}$ On the other, there are documentary sources that cast doubt on whether guilds were sufficient to create such trust. Court records, petitions, and official reports from most early modern European industries make it clear that if guild rules created trust between masters and apprentices, this trust was often misplaced. Masters throughout early modern Europe profited by taking on apprentices to whom they did not pay wages on the grounds that they were educating them, and then exploiting them as cheap agricultural and household labour instead of training them. Apprentices throughout early modern Europe violated their masters' trust by shirking their lessons and absconding before they had repaid the master for his investment in their training. ${ }^{99}$

Many guilds passed apprentices through to journeymanship, and journeymen through to mastership, without actually examining their skills in any serious way. In many - perhaps most - early modern crafts, apprenticeship certificates were issued automatically at the end of a certain period of years, without the trainee's even going through the formality of an examination. Most guilds required a journeyman to produce a masterpiece and be examined on it. But in practice, if the journeyman satisfied the other entry requirements (male gender, payment of fees, minimum period of tramping, appropriate confessional affiliation, community citizenship, etc.), the quality of his masterpiece often played little or no role in his being awarded a mastership license. ${ }^{100}$

That guilds conferred mastership licenses without seriously testing skills was widely recognized by contemporaries. Thus, for instance, in 1669 a guilded bathman and surgeon in the small Bohemian town of Friedland petitioned for protection against a wide array of

\footnotetext{
${ }_{98}^{97}$ Pfister, The Craft Guild as a Firm, pp. 10-11.

${ }^{98}$ K. D. M. Snell, Annals of the Labouring Poor: Social Change and Agrarian England, 1660-1900, Cambridge 1985, pp. 228-9, 278, 312-13; D. Simonton, Apprenticeship: Training and Gender in Eighteenth-Century England, in: M. Berg (ed.), Markets and Manufacture in Early Industrial Europe, London, 1991, pp. 227-258, here esp. p. 229; Lipson, History, pp. 60-1; T. K. Dennison, Apprenticeship in 19th-Century Russia: Evidence from Yaroslavl Province, paper presented at the European Social Science History Conference, Berlin, March 2004.

${ }^{99}$ Ogilvie, Bitter Living, pp. 98-9; G. Riello, The Shaping of a Family Trade: the Cordwainers Company in Eighteenth-Century London, in: Gadd / Wallis, Guilds, pp. 141-159, here p. 149; Stabel, Guilds, pp. 201-2.

${ }^{100}$ Ogilvie, Guilds, Efficiency, and Social Capital, pp. 311-12; Riello, Shaping, pp. 150-2.
} 
competitors - including an executioner's widow and several old village women - to whom local patients were flocking. Overlords in eastern Europe under the second serfdom were generally not as indulgent to guilds as community authorities in central and western Europe, and the Friedland manorial court rejected the guild master's petition, pointing out that it is not sufficient in itself that the petitioner has gone through his apprenticeship years and journeymanship years, but besides this, skill [die Kunst] is required; now since it is common knowledge that this man not only is unfortunate in his cures, but also does not grasp his profession and skill [Kunst] as he should, therefore patients cannot be forbidden to beserve themselves of alternative assistance and have themselves cured by others. ${ }^{101}$

Even in such a highly skilled activity as medicine, seventeenth-century customers showed a clear-sighted recognition that guild apprenticeship and journeymanship were not sufficient for guaranteeing skills, and that untrained old women and 'untouchable' executioners' widows might be trusted to practise this activity with much greater skill than a guild-trained master.

Such examples can be multiplied for guilded activities throughout pre-industrial Europe. 'Encroachers' who failed to secure guild training - often, as in the case of females, because guilds excluded them from formal apprenticeship and journeymanship ${ }^{102}$ - were bitterly opposed by early modern guilds. This was not because encroachers passed off lowquality wares under the guild trademark: as we saw in the preceding section, many guilds did not police quality seriously, whether from incapacity, weak incentives as monopolists, or a combination of both. Rather, guilds opposed non-guild-trained 'encroachers' so bitterly precisely because the wares and services they provided were just as attractive to customers as those of guild-trained masters. ${ }^{103}$ Women, Jews, and other excluded groups were perceived by guild masters throughout Europe as serious competitors, despite being visible minorities whom customers could easily identify as non-possessors of guild training. If the mutual trust created by guilds really had resulted in more appropriate levels of skilled training than were manifested by unguilded producers, then guilds would not have had to use legal coercion to compel customers to consume their products rather than those of 'inadequately' trained outsiders. Nor would individual guild masters have been so keen to employ non-guild-trained

\footnotetext{
${ }^{101}$ Státní Oblastní Archiv Litoměřice, Pobočka Děčín, Fond Rodinný Archiv Clam-Gallasů, Historická Sbírka, Karton 81, Dekretbuch Frydlant 1669-72, 2.12.1669, fol. 1: 'Eß ist nicht an dem genug, daß d. Supplicant seine Lehr: vndt wander Jahr außgestanden, sondern es wirdt darneben die Kunst Er fordert; Alldieweiln nun die Gemeine Rede durch gehend dahin Ziehlen thuet, daß derselbe in seinen Curen nicht allein Vnnglückseelig, sondern auch seine profeßion Vnd Kunst, nicht, wie es sein soll, begriffen, Alß ist denen Patienten nicht $\mathrm{Zu}$ Verdencken, daß dieselbe sich anderer hülffe bedienen, Vndt bey Andern Curiren Lassen'.

${ }^{102}$ For a detailed discussion of the few, exceptional cases (mainly medieval) in which guilds admitted girls as apprentices, see Ogilvie, Bitter Living, pp. 96-7; L. Roper, The Holy Household: Women and Morals in Reformation Augsburg, Oxford 1989, pp. 44-9; Stuart, Defiled Trades, pp. 213-9; Hafter, Underground, pp. 14-18, 27-32; Rule, Property, 107.

${ }^{103}$ For examples of black-market producers more than skilled enough to compete with guild masters, see, for instance, Hafter, Underground, 16-8, 30-2; Homer, The Pewterers Company's Country Searches, p. 105; Ogilvie, Bitter Living, pp. 130-4, 260, 263, 305-8.
} 
free-lancers, whom they evidently trusted to produce work of sufficient quality not only to satisfy customers but also to pass guild quality inspections.

Guilds were thus in many cases not an optimal institution for ensuring appropriate training, even in those activities which did require high levels of skill. It seems likely that it was theoretically inevitable as well as empirically widespread for guilds to issue licenses to masters who did not 'grasp their profession and skill as they should'. As associations of masters, guilds had strong incentives to certify members' sons without question and to permit opportunism by masters who could not be bothered to train their apprentices or journeymen. That is, having once used their social capital to foster a particularized trust in persons with a particular group affiliation, guilds had incentives to abuse that trust for the profit of their members.

The recognition that guilds had incentives to abuse their trust to benefit their members leads to a third question. Given that apprenticeship, journeymanship, and mastership regulations could in theory function both to encourage training and to exclude outsiders, which predominated in practice? There is certainly plenty of evidence to indicate that guilds did use training regulations to exclude outsiders, thereby reducing competition for their own members. Wherever early modern guilds had the power to do so, they used their apprenticeship, journeymanship, and mastership regulations to exclude not only women, Jews, and bastards, but also members of other Christian confessions than the local one, Roma, foreigners, serfs, members of 'untouchable' occupations, paupers, individuals unable to pay admission fees and provide deposits, and in many cases anyone who was not the son of a local citizen or an existing guild master. ${ }^{104}$ It is often claimed that such admission barriers were not binding constraints and did not prevent entry. But documentary sources suggest that guild fees and other requirements did exclude many applicants - and where they did not, it was because the guild was too weak to enforce them rather than because it was uninterested in doing so.

In particular, guilds' contradictory treatment of women demonstrates clearly that guild rules on training were directed not at using trust to encourage optimal levels of human capital investment, but at abusing the trust of customers by protecting established producers from competition. Girls were almost invariably excluded from guild training, except in a few large cities where they were allowed to join guilds in 'feminine' crafts such as mantuamaking or embroidering. When unmarried females nevertheless practised guilded activities, they were harshly penalized as 'encroachers'. Yet black-market female encroachers were skilled enough to produce wares that satisfied the requirements of customers and merchants

\footnotetext{
${ }^{104}$ Bos / Lourens / Lucassen, Zünfte, pp. 134-5; Forbes, Search, pp. 120-1; Lis / Soly, Zünfte, pp. 167, 170-1; Lucassen / Prak, Guilds and Society, pp. 66-7; Ogilvie, State Corporatism, pp. 45-57, 127-80; Pfister, The Craft Guild as a Firm, p. 6; Stabel, Guilds, pp. 194-5; Stuart, Defiled Trades, pp. 213-19.
} 
and (when such women worked illegally for guild masters) also to make wares that passed guild inspectors. Women without formal guild training engaged in skilled craft work throughout pre-industrial Europe, wherever guilds failed to put them out of business. ${ }^{105}$

At the same time, wives of guild masters were generally permitted to engage in any craft task, and masters' widows were often allowed to inherit the guild workshop. In some important guilded industries in early modern Europe, 15-30 per cent of workshops were operated by widows. ${ }^{106}$ Such widows did not simply carry over workshops for brief transitional periods, but often operated them for decades. Furthermore, a wife's or widow's guild license was seldom made conditional on the length of time she had been married. In one guilded industry where detailed figures are available, 20 per cent of practising widows had been married for a shorter period of time than the minimum duration of male apprenticeship and journeymanship combined. ${ }^{107}$ Nor did widows generally work through trained male employees: widows were almost invariably forbidden to employee cheap apprentice labour, and journeymen were so costly than only a tiny minority of masters - male or female - could afford to employ them. The vast majority of widows produced the wares themselves, without guildtrained male assistants. ${ }^{108}$

This contradictory treatment by guilds of different groups of untrained females casts serious doubt on the idea that guild training regulations were directed at fostering a social capital of trust to solve imperfections in markets for human capital investments rather than at excluding outsiders so as to reduce competition. On the one hand, a non-trivial group of untrained women with legal entitlements from the guild as masters' wives and widows was permitted and able to produce wares which passed guild and merchant inspections and sold successfully on markets. On the other, vast numbers of similarly untrained women - and men who lacked such entitlements and were capable of doing the same activities were forbidden to do so on the grounds that they had not undergone guild apprenticeship. Indeed, the strong objections of London companies to aliens practising craft occupations in the sixteenth and seventeenth centuries were intensified 'by the fact that these foreign craftsmen were often more

\footnotetext{
${ }^{105}$ Hafter, Underground, pp. 14-18, 27-32; M. C. Howell, Women's Work in the New and Light Draperies of the Low Countries, in: Harte, New Draperies, pp. 197-216, here p. 200, 206-10, 212; Ogilvie, Bitter Living, pp. 96-9, 127-8, 153-9, 232-6, 295-8; Roper, Holy Household, pp. 44-9; Rule, Property, , p. 107; K. Simon-Muscheid / G. Jacobsen, Resümee, in: K. Simon-Muscheid (ed.), Was nützt die Schusterin dem Schmied? Frauen und Handwerk vor der Industrialisierung, Frankfurt / New York 1998, pp. 159-65, here p. 163; Simonton, Apprenticeship, $230 ; M$. Sonenscher, The Hatters of Eighteenth-Century France, Berkeley, 1987, pp. 35-6; Stuart, Defiled Trades, pp. $213-$ 19; Lis / Soly, Zünfte, pp. 158-9.

${ }^{106}$ For examples, see Ogilvie, Bitter Living, p. 260; Ogilvie, Guilds, Efficiency, and Social Capital, p. 305 (Table 3); M. van Dekken, Women and Work in the Early Modern Netherlands: the Production of and Trade in Beverages, paper presented at the European Social Science History Conference, Berlin, March 2004.

${ }^{107}$ Ogilvie, Guilds, Efficiency, and Social Capital, pp. 304-07, esp. Table 4.

${ }^{108}$ For more detailed discussion, see Ogilvie, Bitter Living, p. 260; Ogilvie, Guilds, Efficiency, and Social Capital, 304-07; S. Ogilvie, Women and Labour Markets in Early Modern Germany, in: Jahrbuch für Wirtschaftsgeschichte, 2004:2 (2004), pp. 53-88, here esp. pp. 75-8.
} 
highly skilled than their native counterparts' ${ }^{109}$ Such findings suggest that the exclusionary functions of apprenticeship, journeymanship, and mastership outweighed their training functions.

This raises to a further question. Did human capital investment fail in crafts which lacked guilds? No. Human capital investment did not require guilds. In the guilded economies of central and southern Europe, apprenticeships were indeed enforced by guilds. But in weakly guilded or unguilded economies such as England, Flanders, and even Russia, apprenticeships were voluntarily entered into by trainees and trainers, who registered their apprenticeships as private contracts in the market and enforced them (where necessary) in courts of law. ${ }^{110}$ In the West of England, for instance, 'formal apprenticeship was almost entirely lacking ... but all trades observed "colting", the customary form of apprenticeship of being "brought up in the trade" which ... did have full legal sanction' ${ }^{111}$ In the West Riding of Yorkshire, apprenticeship survived very widely, but as a voluntary contract between individuals rather than a guild requirement - in the words of one eighteenth-century clothier, 'rather from custom than from a sense of the Law'. ${ }^{112}$

In certain respects, apprenticeships were more widely available in weakly guilded economies such as the Low Countries and England, because they were open to those whom guilds usually excluded - children who could not afford high guild premiums, females, and even Jews. ${ }^{113}$ Thus girls made up 9 per cent of all apprentices registered in Essex and Staffordshire in the second half of the eighteenth century, and fully 33 per cent of all apprentices put out to training by their parishes. ${ }^{114}$ By contrast, in the Württemberg district of Wildberg among apprentices registered by the worsted-weavers' and bakers' guilds between 1597 and 1760, or put out to parish apprenticeships by the communal church courts between 1645 and 1800, the percentage of girls was zero. ${ }^{115}$

Apprenticeship was thus a widespread institution for transmitting human capital in early modern Europe, with or without guilds. The difference was that unguilded economies let producers decide for themselves what level of skill to invest in, privately contract in markets to secure craft training, and bring violations of training contracts before state courts for punishment. ${ }^{116}$ This permitted apprenticeships to decline in sectors where lengthy training

\footnotetext{
${ }^{109}$ Forbes, Search, p. 121.

${ }^{110}$ Snell, Annals, pp. 228-9, 278, 312-13; Simonton, Apprenticeship, esp. p. 229; Lipson, History, pp. 60-1; Dennison, Apprenticeship in 19th-Century Russia.

${ }^{111}$ Randall, Before the Luddites, p. 33.

${ }_{112}$ Quoted in Heaton, Yorkshire, p. 308

${ }^{113}$ On the wide variety of types of apprenticeship found in early modern England, including ones involving very low premiums, female apprentices, and even female masters, see Simonton, Apprenticeship, esp. pp. 229, 233, 245. On the admission of women and Jews to crafts in the United Provinces and the Southern Netherlands, see Bos / Lourens / Lucassen, Zünfte, pp. 134-5; De Vries / Van der Woude, First Modern Economy, pp. 598-600; Lis / Soly, Zünfte, p. 159; Lourens / Lucassen, Gilden und Wanderung, pp. 77 with note 30; Ogilvie, Bitter Living, pp. 345-6.

${ }^{114}$ Simonton, Apprenticeship, p. 245.

115 Ogilvie, A Bitter Living, pp. 96-9.

${ }^{116}$ On the decline of apprenticeship among London cordwainers (shoemakers), see Riello, Shaping, pp. 143-9.
} 
was irrelevant - such as low-skilled linen or worsted industries addressing cheap mass markets - but flourish in skilled crafts where formal training enhanced productivity.

Nor were guild apprenticeships necessarily any more effective than non-guild ones. The shared norms and collective sanctions provided by guilds may have enabled masters to discipline shirking apprentices but it hardly gave the latter much recourse against shirking masters. Shirking masters clearly existed in strongly guilded economies. Thus, for instance, in 1624 the Württemberg orphan Bastian Heckh ran away from his master because 'the master made use of the lad all the time in the vineyard and in the fields' ${ }^{117}$ In 1798 , likewise, the grandfather of the Württemberg apprentice Johannes Ischinger removed him from his master because he 'was being held to hard work in the fields'. ${ }^{118}$ But such masters were seldom prosecuted by guilds: the 653 offences fined by the worsted-weavers' guild in Württemberg district of Wildberg between 1597 and 1760 included only one penalty inflicted on a master for failures of training (he neglected to set up the equipment for his apprentice before letting him begin weaving). ${ }^{119}$

It is therefore not clear that training contracts were better enforced or human capital more effectively transmitted in guilded economies than in those in which guilds were weak or absent. In England or the Netherlands, a dissatisfied master or apprentice had to take his complaint to the state - a Justice of the Peace, a community council sitting, a state court. But in strongly guilded Württemberg, that is what apprentices and their families had to do anyway, since guilds of masters were, understandably, not highly motivated to penalize masters who failed to treat their apprentices properly. In 1624 Bastian Heckh absconded from his neglectful master "with the idea that he would probably find a master who would finish his training', but ended up having to get his guardians to sue his equally neglectful and abusive new master before a community court chaired by a princely district official. ${ }^{120}$ In 1798 , Johannes Ischinger's grandfather had to take his grandson away from his neglectful master 'arbitrarily' in order even to gain a hearing from the community court. ${ }^{121}$ In an economy with weak guilds or none, a neglected apprentice might even gain fairer justice than in a guilded one, since courts would be less subject to guild pressure, and thus less likely simply to order, as the Wildberg authorities did, that 'Young Ischinger be given back to ... his master according to the contract that had been concluded'. ${ }^{122}$

\footnotetext{
${ }^{117}$ HSAS A573 Bü. 16, fol. 60v, 3.6.1624: 'Selbig. maister, den bueben immertz in weingart. vndt vff dem feldt gebraucht'.

${ }^{118}$ Pfarrarchiv Wildberg (hereafter PAW), Kirchenkonventsprotokolle (hereafter KKP) Vol. VIII, fol. 94r, 22.6.1798: 'zu harten Feld Geschäften angehalten werde'.

${ }^{119}$ Ogilvie, State Corporatism, p. 330.

${ }^{120}$ HSAS A573 Bü. 16, fol. 60v, 3.6.1624: 'er wolle wohl ein maister bekommen, der ihne vßlehrne'.

${ }^{121}$ PAW, KKP Vol. VIII, fol. 94v, 22.6.1798: ‘eigenmächtig widerum abgenommen habe’.

${ }^{122}$ PAW, KKP Vol. VIII, fol. 94v, 22.6.1798: ‘der Junge Ischinger seinem Meister ... nach dem getroffenem Contrakt zurükgegeben'.
} 
Even in cases where the state failed to dispense uniform justice, in an unguilded economy the neglected apprentice had another 'uniform' institution to turn to: he could seek training elsewhere in an open labour market that did not grant 'differential' privileges to guild masters; he could even obtain training informally (e.g. through 'colting') without subsequently being denied the right to practise as a master. This option was closed to him in a guilded economy where he was legally obliged to stay with his master, other guild masters were forbidden to accept absconding apprentices without lengthy formalities, and someone who absconded from a neglectful master would be forever denied permission to set up in business independently. In England, when a weaving master failed to train his apprentice satisfactorily, the apprentice typically sought training elsewhere, whether formally or informally. ${ }^{123}$ Thus, for instance, the eighteenth-century apprentice Hirst absconded from a cruel master, but nevertheless rose to become a prominent Yorkshire textile manufacturer. ${ }^{124}$ Notwithstanding the absence of guild apprenticeships, according to one eighteenth-century Yorkshire master clothier 'we think it a scandal when an apprentice is loose if he is not fit for his business; we take pride in their being fit for their business, and we teach them all they will take'. ${ }^{125}$ Comparisons across European economies thus show both that training contracts were widespread without guild intervention, and that in the absence of guild privileges states and markets enforced training contracts in the interests not just of masters but also of apprentices.

This raises a final question. Were early modern industries with strong guild structures also the ones that achieved optimal levels of training? Our best measure of an optimal level of training is that which enabled a group of industrial producers most successfully to satisfy customers and expand sales. From the later fifteenth century on, as we saw in the previous section, the same industry might be strongly guilded in one part of Europe, weakly guilded in another, and totally unguilded in a third. Yet those groups of European producers that possessed the optimal level of skills for satisfying customers were not the ones with the strongest (or necessarily any) guilds. Thus, as already mentioned, expanding groups of protoindustrial producers in the Low Countries and England escaped guild training almost wholly, yet produced their wares with sufficient skill to attract, retain, and expand their international customer base. The most successful and dynamic worsted industries, for instance - those in sixteenth- and seventeenth-century Flanders and eighteenth-century Yorkshire - either relaxed guild training requirements or abandoned them altogether. ${ }^{126}$ The same was true of many other crafts and industries that successfully addressed the expanding consumer markets of the early modern period, as shown by the decline of apprenticeship among London

\footnotetext{
${ }^{123}$ See the examples discussed, for instance, in: Lipson, History, pp. 74-8.

${ }^{124}$ Lipson, History, pp. 76-7.

${ }^{125}$ Quoted in Lipson, History, p. 75.

${ }^{126}$ For a detailed analysis of these issues across different European worsted industries, see Ogilvie, Guilds, Efficiency and Social Capital, pp. 312-14.
} 
cordwainers (shoemakers) between the sixteenth and seventeenth century. ${ }^{127}$ As early as 1669 , the English Privy Council declared that although the 1563 Statute of Artificers requiring any craftsman to have served a seven-year apprenticeship had not been repealed, nevertheless it 'has been by most of the Judges looked upon as inconvenient to Trade and to the Encrease of inventions'. ${ }^{128}$

In questions of human capital investment, therefore, some European economies continued into the eighteenth or nineteenth century to rely on the 'particularized' trust in persons with known group affiliations and 'differential' trust in guilds as the institution for enforcing training contracts. But other economies began as early as the sixteenth or seventeenth century to shift towards a 'generalized' trust which applied even to strangers underpinned by a 'uniform' trust in an impartial institutional framework of markets and states that enforced contracts regardless of personal attributes of the contracting parties.

Precisely how and why this shift from 'particularized' to 'generalized' trust occurred awaits full clarification, and is one of the most important questions facing both economic historians of early modern Europe and economists analysing modern developing economies. But the evidence on guilds suggests that - at least in European economic development particularized trust may not have encouraged generalized trust (as social capital theorists would have it), but rather may have substituted for it. Early modern economies tended to rely in matters of human capital investment either on a particularized trust in guild members linked to a differential trust in guilds as institutions, or on a generalized trust in strangers mediated by a uniform trust in impersonal markets and impartial states, but not both simultaneously. This is not surprising, since particularized trust in persons of known attributes and differential trust in guilds meant that certain markets (e.g. for industrial training) were only accessible to persons licensed by the appropriate guild, and the state's contract enforcement was also biased toward members of that group. In other words, members of early modern economies that were highly guilded may not have been able to afford to evince generalized trust in strangers or a uniform trust in impartial markets and states because the prevalence of particularized trust in guild members and differential trust in guilds prevented markets and states from being impartial.

\subsection{Guilds, Trust, and Technology}

The market for information - particularly for technological innovations - is the third sphere in which guilds are supposed to have used their social capital to create trust that benefited the entire economy. The idea that special institutional arrangements may be necessary to deal with new technological ideas is based on the recognition that markets for information have

\footnotetext{
${ }^{127}$ Riello, Shaping, pp. 143-9.

${ }^{128}$ Quoted in Forbes, Search, p. 121.
} 
imperfections that can impede innovation. Information is a 'public good': it is 'nonexcludable' (once an idea has been sold to one consumer, it is hard to prevent it from being communicated without charge to others) and 'non-rival' (the producer of an idea incurs no higher costs by providing it to extra consumers). These characteristics mean that the social benefits of public goods such as information may exceed their private benefits. As a result, ideas and information about them will tend to be under-provided by private individuals transacting in markets. Innovative ideas may be either not invented at all, since potential inventors cannot profit from their own efforts; or invented but diffused only to a few paying customers so that private inventors can profit, even though at zero additional cost these ideas could benefit society more widely.

Guilds, it is sometimes argued, solved these problems. First, they are supposed to have operated much in the manner of a patent system, by creating monopoly rents for innovators, thereby overcoming the disincentives to innovation created by the fact that it is difficult to exclude users of new information. Second, guilds are regarded as having overcome barriers to the diffusion of new practices, by obliging all practitioners to seek work outside the local area for a minimum period as journeymen before becoming masters. Third, guilds are portrayed as guaranteeing the smooth transmission of technical expertise across generations by requiring all practitioners to undergo guild apprenticeship. And finally, guilds are supposed to have eased horizontal technology transfers by promoting the spatial clustering of craft practitioners. ${ }^{129}$

All these arguments are based on the idea that guilds favoured technological innovation by generating a differential trust in themselves as institutions and a particularized trust in their members. All are theoretically possible. But none as yet enjoys convincing empirical support. And there are both theoretical and empirical arguments that cast doubt on the idea that guilds in general used their trust to foster innovation in these socially beneficial ways.

The first argument is that guilds created among their members a trust in the guild as an institution that would ensure that the right to make use of any new techniques they might invent would be restricted, along with the practice of the occupation, to the narrow circle of guild members, thereby guaranteeing a future stream of monopoly rents to reward current investment in innovation. This is based on an idea advanced many years ago by Joseph Schumpeter, that a producer with a monopoly in a particular sector will have a greater ability to innovate than his competitive counterpart because monopoly profits will relax funding constraints on R\&D investment, and that he will have greater incentive to innovate because he

${ }^{129}$ Epstein, Craft guilds, pp. 693-705; Reith, Technische Innovation, pp. 43-9. 
stands to lose so much more. ${ }^{130}$ This theoretical proposition has been explored exhaustively by economic theorists, and is often invoked in modern antitrust cases. ${ }^{131}$

However, the empirical support for it has always been ambiguous. For one thing, while it is often the case that large firms innovate more, it may be their size (and thus the economies of scale they can reap) rather than their market dominance that gives them the finance or incentive to do so. Second, while unusually profitable firms do often innovate more, it may be that the causation runs from innovation to profitability rather than vice versa. Third, financing incentives created by a monopoly are difficult to disentangle from the effects of demand-pull, which increases both profits and inventive effort. Finally, monopoly profits are only one of many possible funding sources for investments in innovation. ${ }^{132}$

The predictions of economic theory on the relationship between monopoly and innovation are also ambiguous. As Scherer and Ross put it, 'through an astute choice of assumptions, virtually any market structure can be shown to have superior innovative qualities. ${ }^{133}$ Furthermore, even economic models that show how a monopolistic market structure could favour innovation require there to be no barriers to entry. That is, for the monopolist to have good incentives to innovate, in these models it must be possible for a potential competitor who comes up with a new technique or product that might threaten the monopolist's rents actually to enter the market. If there are barriers to entry - such as guild licensing restrictions - that limit the number of producers and prevent potential competitors from entering the market, then the monopolist loses any special incentive to invest in innovation. ${ }^{134}$

Pre-industrial guilds could certainly provide their members with monopoly rents, assuring masters that the right to practice the occupation would remain restricted to the narrow circle of guild members, and thus that any innovations in that sector would be rewarded by a future stream of monopoly rents. These rents might have increased a craftsman's incentive to incur the costs of developing an innovation compared to a normal competitive market where he would not have been able to charge monopoly prices. But guilds created these rents by erecting barriers to entry - by using apprenticeship, journeymanship, and mastership requirements to limit the number of producers and prevent potential competitors from moving into the market. Moreover, guilds limited workshop size, fixed

\footnotetext{
${ }^{130}$ J. Schumpeter, Capitalism, Socialism, and Democracy, New York 1942, esp. chapter 8.

${ }^{131}$ From a voluminous literature, see K. Arrow, Economic Welfare and the Allocation of Resources for Invention, in: R. Nelson (ed.), The Rate and Direction of Innovative Activity, Princeton 1962, pp. 609-25; and the studies surveyed in F. M. Scherer / D. Ross, Industrial Market Structure and Economic Performance, 3rd edn, Boston 1990, pp. 630-51.

${ }^{132}$ See the discussion in Scherer / Ross, Industrial Market Structure, pp. 630-1, 644-51.

${ }^{133}$ Scherer / Ross, Industrial Market Structure, pp. 630, 642 (quotation).

${ }^{134}$ On the key role played by lack of barriers to entry in theoretical models linking monopoly and innovation, see F. Etro, Innovation by Leaders, in: Economic Journal, 114, 2004, pp. 281-303, here pp. 281-3, 287-9, 298, 300-01; Scherer / Ross, Industrial Market Structure, pp. 635, 637.
} 
output quotas, set prices collectively, and required collective approval and adoption of any new equipment or wares. This prevented potential innovators from undercutting their fellows and reaping a greater share of rents. Monopoly rents went to all masters, irrespective of whether they were innovative. Guild entry barriers meant there was no threat that a potential competitor who came up with a new technique could enter the market and threaten members' rents. In short, guilds did generate monopoly rents for their members, but there is no evidence that these rents rewarded innovation.

The second way in which guilds are supposed to have used their social capital to favour innovation was by creating trust within the wider society in the guild as an institution that would compel journeymen to travel. This is supposed to have ensured that, although new techniques remained a monopoly of guild members locally, they were swiftly spread to guilds in other localities. The evidence adduced in support of this idea consists in the fact that many (though not all) guilds required journeymen to travel for a minimum number of years before they were allowed to set in independent practice, and that this was sometimes justified in terms of their learning (though not usually teaching) new techniques during their travels. ${ }^{135}$

However, doubt is cast on this argument by evidence relating to migration in preindustrial European societies. Guilds were certainly not necessary to ensure migration of young workers in early modern Europe, since such workers were highly mobile even in guildless sectors such as agriculture. ${ }^{136}$ Nor were guilds sufficient to ensure migration of young craft workers and the information they embodied. The Netherlands, for instance, enjoyed legendary labour mobility and even more legendary levels of technological innovation in the seventeenth century, while differing from Germany, France, and England in having guilds that did not require journeymen to travel. ${ }^{137}$ Furthermore, as contemporary commentators lamented, many guilds actively excluded any technological innovations that journeymen might have diffused into their home region by prohibiting the settlement of foreign journeymen. ${ }^{138}$ Guild tramping requirements were thus neither necessary nor sufficient for creating the trust to ensure diffusion of new techniques.

The third way in which guilds are supposed to have used their social capital to favour innovation was by enforcing minimum periods of training, thereby encouraging a smooth transmission of technical expertise between generations. That is, guilds created trust among masters that technological secrets they transferred would not immediately be used to set up a competing workshop, but rather delayed for at least the minimum legal duration of apprenticeship and journeymanship. The evidence adduced in support of this proposition is the existence of guild regulations imposing minimum periods of apprenticeship and

${ }^{135}$ As discussed in Ogilvie, State Corporatism, pp. 139-51.

${ }^{136}$ On the mobility of farm servants and agricultural labourers, see Ogilvie, Bitter Living, esp. pp. 114-5, 282-6.

${ }^{137}$ Lourens / Lucassen, Gilden, pp. 73-5, 77, 79. 
journeymanship. In practice, however, as we have seen, many of the most successful early modern European industries increasingly dispensed with guild apprenticeships (or never had them). Yet these industries' growth suggests that they transmitted techniques effectively. Guild apprenticeship and journeymanship, therefore, were neither sufficient nor necessary to ensure effective transmission of technical expertise between generations.

The final way in which guilds are supposed to have used their social capital to favour innovation was by enforcing spatial clustering for purposes of monitoring workshops. This, it is argued, could have created an atmosphere of multiplex interactions and neighbourly trust that favoured horizontal transmission of technical expertise among practitioners. The evidence adduced in support of this proposition is that in many pre-industrial cities members of the same craft clustered in particular streets or neighbourhoods. But other evidence casts doubt on this idea. Guilds were certainly not necessary to bring about spatial clustering: industrial agglomeration is widely observed in most economies, including modern guildless ones, because it brings a whole array of advantages that have been quite thoroughly analyzed by economists. ${ }^{139}$ Nor was spatial clustering either necessary or sufficient for technological transmission: some of the most innovative industries in early modern Europe, particularly in the textile sector, were located in rural areas where producers were scattered across farms and small villages but nevertheless swiftly adopted - and even themselves invented - new wares and practices, often to a degree which urban guild practitioners found deeply annoying. Thus, for instance, the phenomenally successful molleton fabric - a woollen-linen mix - was invented in the Flemish village of Tourcoing in the early eighteenth century by an unguilded rural weaver, and by 1748 was being manufactured by at least 2,000 unguilded producers in that village alone, despite attempts by the Lille weavers' guild first to monopolize the invention and, when this failed, to outlaw it altogether. ${ }^{140}$

Such attempts by guilds to monopolize or outlaw new techniques are observed in most early modern European industries. In these cases guilds, far from using the trust they generated to solve imperfections in markets for innovations, abused their trust to oppose new techniques that threatened members' rents. Enthusiasts for guilds are well aware of this evidence, and seek to dismiss it using four arguments. First, they point out that many industrial innovations in early modern Europe were adopted without being opposed by guilds. Second, they claim that guilds only opposed labour-saving and capital-intensive innovations, while favouring labour- and skill-intensive ones. Third, they contend that many innovations that were opposed by guilds were impractical and would never have been adopted anyway.

\footnotetext{
${ }^{138}$ Troeltsch, Zeughandlungskompagnie, pp. 165-6.

${ }^{139}$ See, for instance, A. Marshall, Principles of Eonomics, 8th edn, London, 1920; orig. publ. 1890), pp. 267-77; M. Fujita /J.-F. Thisse, Economics of Agglomeration, in: Journal of Japanese and International Economies, 10, 1996, pp. 339-78, here pp. 339-41.

${ }^{140}$ DuPlessis, One Theory, pp. 148, 158.
} 
Finally, they argue that even when guilds did oppose innovations it did no harm since innovators simply evaded guild regulations. ${ }^{141}$

It is certainly the case that some industrial innovations in early modern Europe were adopted without detectable guild resistance. If an innovation did not threaten established masters, their guild had no incentive to resist it. But the same guild could bitterly resist other innovations that its members did perceive as endangering their interests. The empirical record suggests that most guilds tolerated innovations that did not threaten their rents while blocking others they perceived as dangerously competitive. ${ }^{142}$ What guilds provided was the means the 'social capital' of mutual trust among guild members lowering the costs of collective action - which established producers could use to resist innovation when they saw it as a threat. The fact that they did not always use their social capital in this way does not mean that they did not do so on occasions when it suited their interests.

Acknowledging the existence of guild opposition to some innovative techniques, enthusiasts for guilds seek to belittle its economic impact by claiming that although guilds did oppose innovations that were labour-saving and capital-intensive, they favoured ones that were labour- and skill-intensive. ${ }^{143}$ Empirically, however, this generalization does not hold. Thus, for instance, urban textile guilds often opposed the adoption of innovative new wares that were more skill-intensive than old ones, but threatened the interests of weaving masters by requiring the removal of guild ceilings on raw materials prices and employees' wages, shifting power to merchants, or enabling some weavers to earn more than others. ${ }^{144}$ Whether a guild opposed a particular innovation was doubtless influenced partly by its factor intensity, but only because that was one contributory factor to the more general issue of how that innovation affected members' rents. This in turn depended on the specific regulations, institutional structure, and political economy of the local industry. It is also important to recognize that even if guilds had only opposed innovations that were labour-saving and capital-intensive, it does not follow that such opposition was harmless. Proponents of such innovations would not have been willing to invest in them had they not believed that they would increase productivity. Blocking such innovations therefore harmed the economy by reducing the amount of output it obtained from a given quantity of inputs. ${ }^{145}$

\footnotetext{
${ }^{141}$ Epstein, Craft Guilds, p. 695; Lis / Soly, Zünfte, pp. 162-3; Pfister, The Craft Guild as a Firm, pp. 13-14; Reith, Technische Innovation, pp. 38-41.

${ }^{142}$ For examples, see Lis / Soly, Zünfte, p. 164; Ogilvie, State Corporatism, pp. 424-31; Ogilvie, Guilds, Efficiency, and Social Capital, pp. 314-5; Pfister, Craft Guilds, pp. 19-20; Pfister, The Craft Guild as a Firm, pp. 13-14; Reith, Technische Innovation, pp. 39-41, 50-3, 56-7; J. K. J. Thomson, Proto-Industrialization in Spain, in: Ogilvie / Cerman (eds.), European Proto-industrialization, pp. 85-101, here p. 88.

${ }^{143}$ Epstein, Craft Guilds, pp. 695-6; Pfister, The Craft Guild as a Firm, pp. 13-14.

${ }^{144}$ Ogilvie, State Corporatism, pp. 352-60; Troeltsch, Zeughandlungskompagnie, pp. 119-21, 161-9, 189-90.

${ }^{145}$ For more detailed exploration of such arguments in the context of guild restrictions on women's work, see Ogilvie, Bitter Living, pp. 346-51.
} 
Another argument by which enthusiasts for guilds seek to belittle the economic impact of guild opposition to innovations is by claiming many new techniques were economically impractical. ${ }^{146}$ But there is a problem with this. If a technique was no good and would not be adopted anyway, then why oppose it? The very fact that a guild mounted costly opposition to a technique suggests that guild masters regarded it as practical enough to harm them. If a technique was impractical, then the guild would have been safe to leave it unopposed. The best guess of modern economic historians must be that early modern guild members were rational and did not invest their resources in mounting opposition to a technique that had no practical implications for them.

The final line of defence is to acknowledge that guilds did try to block some practical innovations, but to claim that such attempts inevitably failed. Thus, it is pointed out, many innovations were secretly adopted after a while. Innovators sometimes forced guilds to liberalize by threatening to emigrate. Guilds in other regions might adopt the innovation anyway, and this put pressure on the original guild to relax its opposition.

But this line of argument - that institutional rules do not matter - has three major problems. First, the fact that regulations are evaded does not make them costless. Concealing forbidden innovations or migrating to a guildless enclave consumed resources which must have deterred the marginal innovator. Furthermore, as shown by analyses of the 'informal' sector in modern less developed economies, the costs of avoiding regulations often exert farreaching effects on the well-being of individuals and the performance of entire economies. ${ }^{147}$

Second, it is a fallacy to believe that the existence of more liberal regimes and threats of emigration by individuals inevitably leads to the liberalization of inefficient institutions as is clearly illustrated by the long survival of eastern European serfdom or the long stagnation of many modern developing economies. Political coalitions, trade protection, market segmentation, transportation costs, and migration restrictions enable many inefficient institutions to survive despite the existence of superior alternatives for generations, sometimes for centuries. ${ }^{148}$ A pre-industrial guild could responded to outside competition either by relaxing its opposition to innovations or by mobilizing its social capital to fortify existing practices. The impact on guilds of competition from more liberal regimes was not inevitable, except perhaps in the very long term. Rather, it depended on the wider political and institutional framework. As discussed below in Section 4, in industries where guilds were able

\footnotetext{
${ }^{146}$ Reith, Technische Innovation, pp. 38-41; Epstein, Craft Guilds, p. 695.

${ }^{147}$ K. Basu, Analytical Development Economics: the Less Developed Economy Revisited, Cambridge MA 1997, pp. 172-3; M. P. Todaro, Economic Development in the Third World, Harlow 1989, pp. 270-1; D. Ray, Economic Development, Princeton NJ 1998, pp. 261, 346-8, 395-6; D. Farrell, The Hidden Dangers of the Informal Economy, in: The McKinsey Quarterly, 2004:3 [http://www.mckinseyquarterly.com/article_page.aspx?ar= $1448 \&$ L2 $=19]$.

${ }^{148}$ See the examples discussed in Ogilvie, State Corporatism, pp. 424-31; Pfister, Craft Guilds, pp. 19-20; Pfister, The Craft Guild as a Firm, pp. 12-13.
} 
to influence the political authorities, they could secure protection enabling them to sustain an inflexible position against competitors for generations or even centuries. ${ }^{149}$

Finally, the argument that guild rules against technological innovations did not matter illustrates a theoretical incoherence at the heart of arguments that social capital and trust are always beneficial. On the one hand, guilds are supposed to have been too weak to abuse their trust in ways that harmed society, but on the other they are supposed to have been strong enough to use it in ways that benefited society. Guilds were simultaneously too weak to enforce regulations hindering innovation but strong enough to enforce regulations encouraging innovation. This position is untenable. One can defend guilds by arguing either that they were so weak they could not abuse their trust or that they were so strong they used their trust to benefit society - but not both at the same time.

Not only does the empirical record show that many guilds did deliberately seek to block new techniques, but it also suggests that many activities guilds undertook for other reasons exerted unintended but far-reaching effects on innovation. Guilds imposed quality regulations stipulating precisely how a product was supposed to be made, claiming that this was important for creating trust between producers and consumers. But such guild rules also deterred innovation by ossifying production methods and excluding even desirable deviations from them. Thus, for instance, guild quality regulations meant that the London pewterers' products were 'governed by tight specifications (and also by regulations prohibiting certain "short cut" manufacturing techniques that were held to be undesirable) and these constraints stifled any move towards competitive innovation'. ${ }^{150}$ This ensured a desirable stream of rents for members of the London pewterers' company, as shown by their willingness to lobby for the confirmation and extension of their regulatory powers into the eighteenth century. But in the longer term, the guilded London pewterers lost their markets to nimble, unguilded Sheffield competitors who devised innovative techniques to create the cheaper and more attractive Britannia metal: 'The over-regulation and conservatism which had inhibited innovation and competition within the traditional pewterer's craft had left most of the oldstyle craftsmen unable to compete in the new industrial world. The company was bypassed $\ldots .{ }^{151}$

Guilds also regulated the prices that producers could charge for wares, in order to foster trust among guild members by reducing inequality and preventing excessive competition. But such rules also deterred innovators by denying them the profits they might hope for if, by using an innovative technique, they could undersell competitors. ${ }^{152}$ Guilds

\footnotetext{
149 Ogilvie, Guilds, Efficiency, and Social Capital, pp. 326-9; and Ogilvie, State Corporatism, pp. 423-43; Pfister, Craft Guilds, pp. 19-23.

${ }^{150}$ Homer, The Pewterers Company's Country Searches, p. 108.

${ }^{151}$ Homer, The Pewterers Company's Country Searches, p. 111.

152 On price-fixing agreements, see Homer, The Pewterers Company's Country Searches, pp. 108-9.
} 
imposed admission restrictions so as to create trust between masters and trainees over training contracts, and between producers and customers over craft skills. But such guild rules also deterred innovation by compelling a limited number of practitioners to spend many years in apprenticeship and journeymanship and endowing masters with a heavy investment in human capital specific to a particular technique and set of products; this gave guild-trained producers strong incentives to resist any technical change that threatened to depreciate that investment. Guilds imposed demarcations between different crafts in order to create trust between producers and consumers over product characteristics and practitioners' skills. ${ }^{153}$ But such guild rules also deterred innovation by preventing the productive exchange of ideas between adjacent bodies of knowledge. In short, rules imposed by guilds to enhance trust in one sphere of activity could have the effect of diminishing trust in another - in this case, to reduce innovators' trust that markets would reward them for inventing, adopting, or disseminating new techniques.

A final reason to question the argument that guild-fostered trust made markets for innovation work better is provided by European comparisons. Not only were many strongly guilded industries technologically backward and stagnant, but many weakly guilded industries were highly innovative. Thus, for instance, the city of Douai in the Southern Netherlands is well-known for lacking guild organizations in the fifteenth and sixteenth centuries, but precisely this allowed 'small producers and merchants to try out new raw materials, explore new ways to acquire them, develop different production techniques, and widen their distribution networks'. ${ }^{154}$ The Dutch city of Leiden was legendary for restricting or altogether banning textile guilds from the later sixteenth century on, yet its flourishing textile sector was in the forefront of technological innovation, introducing hundreds of new varieties of wares and numerous innovative mechanical devices, and remaining one of the most successful and innovative European textile centres until overtaken by cheaper Flemish and English competitors in the later seventeenth century. ${ }^{155}$ The Bruges linen-weavers introduced the technically advanced striped and checked Zingas with wild success in the eighteenth century by circumventing and ultimately abolishing guild restrictions on workshop size and labour practices. ${ }^{156}$ The West Riding of Yorkshire was as close as possible to being wholly unguilded, yet its woollen and worsted industries were the most successful in eighteenthcentury Europe, partly because of their exceptional receptiveness to technological innovations in both process and product. ${ }^{157}$ The weavers, finishers, and merchants of Douai, Leiden, Bruges, or the West Riding devised and adopted new techniques in the belief - which was

${ }^{153}$ Pfister, The Craft Guild as a Firm, p. 3; Stabel, Guilds, p. 197.

${ }^{154}$ Howell, Achieving the Guild Effect, p. 124.

${ }^{155}$ L. Noordegraaf, The New Draperies in the Northern Netherlands, in: Harte, New Draperies, 173-96, here pp. $176,179-83$

${ }^{156}$ Lis / Soly, Zünfte, pp. 162-3. 
evidently justified - that markets functioned efficiently enough to reward them for doing so. This is not to say that alternative institutional arrangements governing technological innovations - a more efficient patent system, for instance - would not have made these markets work even better. But it is clear that guilds were not the solution. On the contrary: unguilded or weakly guilded industries were more often than not at the forefront of inventing, adopting, and diffusing new techniques in early modern Europe.

\section{Guilds and the Abuse of Trust}

In such crucial economic spheres as product quality, human capital investment, and technological innovation, a particularized trust in guild members linked to a differential trust in guild institutions appears to have been less favourable to economic growth than a generalized trust in strangers linked to a uniform trust in impartial states and markets. Counter to the claims of social capital theorists, the particularized and differential trust generated by associative institutions does not seem to have fostered the generalized and uniform trust that makes markets and states work better. ${ }^{158}$ One might, rather, advance the alternative hypothesis that particularized and differential trust blocked the growth of generalized and uniform trust. Early modern European economies either retained powerful guilds, or developed impersonal markets open to all participants irrespective of group affiliation where transactions were enforced by impartial state institutions; but they do not seem to have had both simultaneously.

Why was this so? This is just what historians would like to know. The evidence discussed above suggests that we look more closely at the neglected 'dark side' of social capital. ${ }^{159}$ Once a guild or other social network succeeds in generating 'particularized' trust in its members and 'differential' trust in itself as an institution, it has incentives to abuse this trust by acting collusively to benefit its members at the expense of outsiders and the wider society. The evidence examined here suggests that such abuse of trust is not an incidental manifestation of the occasional 'bad' social network. Rather, it appears to be implied by the very characteristics that enable any social network to generate social capital to begin with.

As already discussed, social capital takes four main forms: the fostering of shared norms; the improvement of information flows about these norms; the punishment of violations against these norms; and the organization of collective action in defence of these norms. Early modern guilds manifested all four, and each involved generating a

\footnotetext{
${ }^{157}$ Heaton, Yorkshire, pp. 264-71; Hudson, Capital, p. 72; Lipson, History, pp. 144-52, 241, 249.

${ }^{158}$ For evidence questioning the existence of any causal link between particularized trust within associations and generalized trust in the surrounding society, see Stolle / Hooghe, Conclusion, pp. 233-5, and the studies cited there. ${ }^{159}$ On the dark side of social capital, see Ogilvie, Bitter Living, pp. 130-8, 172-205, 247-68, 305-19, 329-34, 3404, 352; S. Ogilvie, How Does Social Capital Affect Women? Guilds and Communities in Early Modern Germany, in: American Historical Review, 109, 2004, pp. 325-59; R. Dessí/S. Ogilvie, Social Capital and Collusion: the Case of Merchant Guilds (Long Version), Cambridge Working Papers in Economics No. 417, March 2004.
} 
'particularized' trust in guild members linked to a 'differential' trust in the guild as an institution. But the norms, information, penalties, and collective action fostered by guilds also gave them the incentive and capacity to abuse the trust they generated to benefit their members at others' expense.

Guilds created trust among their members enabling them to coordinate on shared norms. ${ }^{160}$ Enthusiasts for guilds have concentrated on what they regard as beneficial norms: that masters should produce high-quality output, that all producers should secure skilled training, that technological 'mysteries' should be nurtured. But there is nothing guaranteeing that a guild - or any other social network - will use its trust to ensure that members coordinate on norms that are beneficial rather than harmful from the point of view of society as a whole. Early modern guilds also coordinated on other, more questionable norms: that non-members should not practise certain economic activities, that many kinds of people should be excluded from guild membership, that girls should not receive vocational training, that it was dishonourable to outbid one's fellows in paying employees, that guild members should shun Jews, knackers, and bastards.

But were these norms beneficial? The norm that it was wrong to practise an occupation without guild membership served to exclude many producers regardless of how well they could actually do the work. The norm that girls should be denied apprenticeship and women other than masters' widows forbidden to operate workshops protected male guild members from competition and forced many women into marginal, ill-paid, and illegal work. ${ }^{161}$ The norm that it was 'dishonourable' to pay employees a competitive wage caused hardship to thousands of apprentices, journeymen, spinners, and craft labourers, and is likely to have resulted in inefficient resource allocation. ${ }^{162}$ The norm that intercourse with Jews and knackers was 'defiling' was economically inefficient and socially divisive. ${ }^{163}$ As the pioneering social capital theorist James Coleman himself acknowledged, 'effective norms in an area can reduce innovativeness in an area, not only deviant actions that harm others but also deviant actions that can benefit everyone'. ${ }^{164}$ Trust among guild members in early

\footnotetext{
${ }^{160}$ Stabel, Guilds, p. 196.

${ }^{161}$ On guilds' discrimination against women, see Clasen, Augsburger, pp. 130-3, 323-5; R. M. Dekker, Women in Revolt: Collective Protest and its Social Basis in Holland, in: Theory and Society 16, 1987, pp. 337-62, here p. 347; Gadd / Wallis, Introduction, pp. 7-8; M. C. Howell, Women, Production, and Patriarchy in Late Medieval Cities, Chicago 1986, pp. 70-94, 124-58, 167; E. W. Monter, Women in Calvinist Geneva, Signs 6, 1980), pp. 189 209, here pp. 202-3; E. Musgrave, Women and the Craft Guilds in Eighteenth-Century Nantes, in: G. Crossick (ed.), The Artisan and the European Town, 1500-1900, Aldershot, 1997, pp. 151-71, here p. 167; Ogilvie, Bitter Living, pp. 40-54, 323; Ogilvie, How Does Social Capital Affect Women?; J. H. Quataert, The Shaping of Women's Work in Manufacturing: Guilds, Households and the State in Central Europe, 1648-1870, in: American Historical Review, 90, 1985, pp. 1122-48, here pp. 1126-7, 1147-8; Roper, Holy Household, pp. 48-9; Wiesner, Working Women, pp. 150-1.

162 Ogilvie, Bitter Living, pp. 214-5, 278-9.

${ }^{163}$ On pre-industrial guilds' discrimination against women, Jews, bastards, and members of dishonourable occupations, see Roper, Holy Household, pp. 36-55; Ogilvie, State Corporatism, pp. 336-8; Stuart, Defiled Trades, pp. 189-221; Ogilvie, Bitter Living, pp. 130-4, 162-70, 259-67, 300-8, 329-31, 340-4.

${ }^{164}$ Coleman, Social Capital, p. 23.
} 
modern Europe penalized 'deviant' actions - occupational mobility, independent work by women, competitive wages for the poorest workers, non-monopolistic commerce, and moves to break down gender and racial discrimination - that could have benefited everyone, except possibly a small group of established male guild masters (and in the long term even they might have done better had they been able to coordinate on deviating from corporative norms). ${ }^{165}$

The second way guilds used trust was to improve the flow of information among members. They did so by employing inspectors and spies to report offences against guild norms and by holding assemblies at which members were required to report any information that affected guild interests. Guild activities were often closely integrated into communal assembles and court sittings, so that violations of guild norms swiftly became known to the wider community. ${ }^{166}$ These information-transmission mechanisms indeed ensured that guild members were aware of each other's personal characteristics and actions, and that such information was also conveyed into the wider economic world of their suppliers, employees, and customers. Enthusiasts for guilds have focussed on the benefits of this social capital of mutual information: it enabled customers to trust producers on product quality, masters to trust employees on human capital investment, and all guild members to trust that technological innovations would profit the membership. But this social capital of mutual information was also used for harmful ends. The activities of guild inspectors, the obligation to report known offences at guild assemblies, and the integration of guild with communal, manorial, and princely regulatory mechanisms enabled guilds to exclude non-members from economic activity, enforce output quotas, prevent adoption of new techniques, limit apprenticeship by outsiders, and penalize black-market work by women - to abuse their particularized trust of shared information in order stifle 'innovations' that could, in Coleman's formulation, have benefited everyone. ${ }^{167}$

The third way guilds used trust was to facilitate group action against violations of their norms. Guilds were entitled to punish a wide range of offences relating not only to the economic activities over which they claimed control but also to the social, sexual, and cultural behaviour of their members. ${ }^{168}$ Again, enthusiasts have focussed on those manifestations of group action that can be regarded as beneficial: collective sanctions against violations of quality codes, against economic activity by untrained producers, against adopting capital-

\footnotetext{
${ }^{165}$ On how social capital in modern societies reinforces uncivic predispositions and strengthens existing cleavages and exclusion patterns, see Stolle / Hooghe, Conclusion, pp. 235-6; Molenaers, Associations, pp. 126-7.

166 Ogilvie, State Corporatism, pp. 316-21; Wallis, Controlling Commodities, pp. 86, 88.

167 On how associations in modern LDCs use social capital to exclude the poor, see Molenaers, Associations, pp. 119-20, where a poor farmer in Nicaragua was asked, 'Why don't you join one of the organizations?', and answered, 'Because they don't let me ... the leaders decide who is going to be in the group and they always pick the same ones ... they are getting all the benefits and we never get anything'.

${ }^{168}$ Ogilvie, Guilds, Efficiency, and Social Capital, pp. 325-6; Ogilvie, State Corporatism, pp. 333-8; Wallis, Controlling Commodities, pp. 88-9; Stabel, Guilds, pp. 192-3.
} 
intensive technological innovations that threatened to put other members out of business. But was this social capital of collective sanctions always beneficial? Collective sanctions were also used to sustain guild members' monopoly over the occupation, to help masters collude to pay non-competitive wages to employees, to enforce cartelistic output quotas which kept prices high for customers, to penalize employers who failed to discriminate against female workers, to put pressure on outsiders to become members of the guild, and to sanction those who associated with 'defiling' social groups. ${ }^{169}$ In the light of such evidence, one must surely question whether guilds' use of trust to impose collective sanctions was truly beneficial to the wider economy and society. ${ }^{170}$

The fourth way guilds used their social capital of trust was to organize collective political action - in Robert Putnam's formulation, to 'monitor' the actions of government. ${ }^{171}$ It is evident from surviving petitions, town council minutes, and princely deliberations that early modern European guilds were active in monitoring - indeed, lobbying - all levels of government to ensure that 'appropriate' political, legislative, and executive decisions were taken. ${ }^{172}$ Guild members invested substantial quantities of time and money in petitioning, lobbying, and demonstrating so as to put pressure on the political process in order to ensure that policies reflected their interests. ${ }^{173}$ Enthusiasts for guilds and social capital have concentrated on what they regard as the beneficial aspects of this collective political action in particular, the ability of guilds to monitor government and hold it to account in a quasi'democratic' sense that benefited the entire society, guild members and non-members alike. It was this political activity by guilds, according to Robert Putnam, that underlay the beneficent development of guilded Northern Italy compared to the politically and socially dysfunctional Italian South. ${ }^{174}$

But did it truly benefit either the early modern state or the early modern economy for guilds to use their trust to organize political action? Well organized corporate groups such as guilds were in a position to offer fiscal support and political cooperation to rulers in tacit exchange for legislation and legal privileges that favoured their members. ${ }^{175}$ Such political favours may have seemed harmless to rulers, or even - if guild rhetoric was to be credited -

\footnotetext{
${ }^{169}$ For a selection of empirical examples, see, for instance, Gadd / Wallis, Introduction, p. 7; Homer, The Pewterers Company's Country Searches, p. 103; Ogilvie, Guilds, Efficiency, and Social Capital, pp. 325-6; Ogilvie, State Corporatism, pp. 321-39; Stuart, Kathy, Defiled Trades, pp. 213-9.

${ }^{170}$ On how trust may be the privilege of 'the winners' and how the benefits of social capital often fail to reach the poor and marginal, see Stolle / Hooghe, Conclusion, pp. 243-3; Molenaers, Associations, pp. 115, 117, 120.

${ }^{171}$ For the view that pre-industrial guilds played an important and beneficial role in monitoring government, see Putnam et al., Making Democracy Work, pp. 163-85; Putnam, Bowling Alone, pp. 319, 322-3, 325, 346-8.

${ }^{172}$ Lis / Soly, Zünfte, pp. 174-8; Ogilvie, State Corporatism, pp. 366-78, 423-43; Pfister, The Craft Guild as a Firm, pp. 2-3, 12-13; Stabel, Guilds, pp. 189-91.

${ }^{173}$ For examples of guild lobbying of early modern governments for legislative favours, see Forbes, Search, pp. 117; Gadd / Wallis, Introduction, p. 6; Homer, The Pewterers Company's Country Searches, p. 102; Ogilvie, State Corporatism, pp. 366-378; Riello, Shaping, p. 143; Wallis, Controlling Commodities, p. 91.

${ }^{174}$ Putnam et al., Making Democracy Work, pp. 163-85.
} 
positively beneficial for the wider society. Such favours also had the great advantage of costing the ruler nothing, at least in the short term. But by limiting economic activity in favour of a producer group in return for a lump-sum payment (or other political benefit) now, a government denies itself the benefits of higher tax revenues through economic growth in future. ${ }^{176}$ Furthermore, when guilds deployed their social capital of particularized and differential trust to lobby governments for market privileges, they may have hindered the spread of generalized trust in strangers and uniform trust in an institutional framework of unrigged markets and impartial state contract enforcement. ${ }^{177}$ In short, the particularized and differential trust associated with social capital may have been an obstacle to the development of the generalized and uniform trust necessary for markets and states to work effectively in ways equally accessible to all economic agents, irrespective of the social networks to which they belonged. ${ }^{178}$ The benefits of particularized and differential trust - such as they were may thus have been secured at a high cost in terms of foregone generalized and uniform trust.

\section{Conclusion: Can We Trust 'Trust'?}

The social capital literature is almost unanimous in holding that modern societies are undersupplied with trust and social capital, and that historical social networks hold important policy lessons. This article has sought to identify the salient features of social capital and the type of trust it generates by examining the most widely admired historical example of social capital the guild. Several general principles emerge from this historical inquiry, but the light they cast on social capital is not encouraging.

Historical networks such as guilds confirm Coleman's view that those social arrangements likely to generate significant trust will be characterized by 'closure' and 'multiplex relationships' ${ }^{179}$ Early modern European guilds carefully regulated membership according to sex, ethnicity, religion, community citizenship, kinship with existing members, and ability to pay license fees. Guilds were not wholly closed to new members, but they limited entrants' quantity and selected their qualities: many members of the wider society had a high probability (or, if female, certainty) of never being admitted to membership in these

\footnotetext{
${ }^{175}$ For more detail, see Ogilvie, State Corporatism, pp. 79-84; Ogilvie, State, pp. 182-99; Ogilvie, Germany,pp. 431-4; Ogilvie, Guilds, Efficiency, and Social Capital, pp. 326-9; Dessí and Ogilvie, Social Capital.

${ }^{176}$ For examples of such payments by guilds to state representatives, see Forbes, Search, p. 118; Ogilvie, Guilds, Efficiency, and Social Capital, pp. 326-9; Ogilvie, State Corporatism, pp. 366-78; Troeltsch, Zeughandlungskompagnie, p. 84; Homer, The Pewterers Company's Country Searches, pp. 103-4.

${ }^{177}$ For evidence from modern Nicaragua on how social capital was used by association members for rent-seeking of donor money and by politicians to recruit clientelistic networks, see Molenaers, Associations, pp. 119-20.

${ }^{178}$ For analogous evidence on modern economies, see Stolle / Hooghe, Conclusion, pp. 236-43; and Molenaers, Associations, 120, where the leader of a local association which generated much social capital in a Nicaraguan village explained, 'I pick the people I know best, the people I can trust. I cannot assume responsibility for people I do not know, because if they 'screw up', then the organization will blame me for it and I will lose the connection.'

${ }^{179}$ Coleman, Social Capital, pp. S104-S110.
} 
social networks and thus never enjoying the benefits of the trust they generated. Early modern guilds also fostered multiplex relationships: their members were linked not just through economic norms, information, sanctions and collective action, but through multi-stranded ties extending into work, play, sociability, worship, politics, charity, and kinship. The evidence on early modern guilds thus confirms that effective social networks are characterized by relationships that are closed toward the outside and multi-stranded on the inside.

The findings on guilds also confirms that trust takes a number of distinct forms, some of which seem to block the development of others. Associative institutions such as guilds foster a particularized trust in persons of known attributes and, as in parts of early modern Europe, this can hinder the spread of the generalized trust in strangers which social scientists regard as extremely important for societies and economies to function well. Privileged, guildlike networks also foster a differential trust in institutions that enforce the rights of certain groups, and this can block the development of a uniform trust in impartial institutions that are open to all - even those without network-specific privileges. ${ }^{180}$

Certain forms of trust are more favourable to economic growth than others. It is sometimes argued that the particularized and differential trust generated by guilds was used to solve imperfections in markets for product quality, human capital investment, and technological innovation in early modern Europe. But the evidence surveyed in this essay suggests that they often failed to do so. The very closure and multiplex relationships that enabled guilds to foster trust created incentives that prevented them from using that trust in ways that benefited the wider economy as opposed to profiting their own membership.

The closure that creates trust means that many network activities are open to abuse. Closure caused guilds to sustain norms privileging a status quo that benefited insiders and discriminated against outsiders. Guilds punished beneficial as well as harmful deviations from their norms and suppressed innovations that could have benefited the wider society. Shared information (e.g. on technology or training) was conveyed to trusted insiders but denied to outsiders. Network membership became a trusted signal ensuring the long-term exclusion of productive economic agents, sustaining discrimination on grounds of gender, ethnicity, religion, legitimate birth, and many other economically irrelevant grounds. Collective political action enabled guilds to engage in rent-seeking and distort markets, harming outsiders and the wider society. The very features that enable social networks such as guilds to generate trust also enable them to act collusively against the common weal. ${ }^{181}$

The final lesson from guild history is at once the most important and most disquieting, especially for modern transitional and developing economies. Even a social

\footnotetext{
${ }^{180}$ On the role of reliable markets and states in creating generalized, uniform trust to supplant the particularized, differential trust associated with associative organizations such as mafias, see Gambetta, Mafia, p. 167.

${ }^{181}$ As pointed out for LDCs by Dasgupta, Economic Progress and the Idea of Social Capital, here p. 367.
} 
network that generates benefits in a given state of technology, costs and incomes, may cease to do so when constraints change. Precisely the trust and commitment devices that generate social capital may also foster conservatism. Thus the guild-dominated societies of northern Italy and southern Germany were unable to adjust to the rapid institutional, commercial and demographic changes of the sixteenth century and lost out to the market-oriented civic culture of the Low Countries and England. While the strong Italian and German guilds possessed enough social capital to entrench themselves against change, the looser and weaker Flemish and English guilds lacked the social capital to put up a fight. The absence of the particularized and differential trust generated by associative institutions such as guilds created interstices within which individuals and rulers could experiment with generalized trust in unknown transaction partners mediated by impersonal markets and impartial states. This cannot be regarded as an accident. To foster trust, social networks need to have closure, information advantages, collective penalties, and commitment devices; once these are in place, it is hard to prevent them from being abused to resist changes that threaten existing benefits.

Even in early modern Europe, where constraints changed so much more slowly than today, the particularized trust and entrenched privileges of social networks could prove a long-term economic obstacle. Nowadays, constraints change immeasurably faster. In such a world, one must question whether poor economies can afford the inflexibility of entrenched social networks that foster a particularized trust in persons and a differential trust in associations rather than a generalized trust in strangers and a uniform trust in impersonal markets and impartial governments. As Partha Dasgupta has trenchantly observed, informal institutions based on social capital may bring certain benefits in less developed economies, but one should not be 'distracted from asking if their continued existence could prevent more productive social arrangements from becoming established, say, in the shape of formal markets. One can even ask whether informal institutions were ever as good as they are frequently made out to have been. ${ }^{, 182}$ It is precisely the strength of social networks - their favouring of trust in a particular set of people over outsiders and their fostering of internal commitment devices - that may be their greatest weakness, not merely for outsiders (although these are often the poorest in society), but also for the economy at large. For the particularized and differential trust fostered by social capital, the lessons of history are bleak.

${ }^{182}$ Dasgupta, Social Capital and Economic Progress, p. 310. 


\section{CESifo Working Paper Series}

(for full list see www.cesifo.de)

1241 Hans Jarle Kind, Karen Helene Midelfart, Guttorm Schjelderup, Corporate Tax Systems, Multinational Enterprises, and Economic Integration, July 2004

1242 Vankatesh Bala and Ngo Van Long, International Trade and Cultural Diversity: A Model of Preference Selection, July 2004

1243 Wolfgang Eggert and Alfons J. Weichenrieder, On the Economics of Bottle Deposits, July 2004

1244 Sören Blomquist and Vidar Christiansen, Taxation and Heterogeneous Preferences, July 2004

1245 Rafael Lalive and Alois Stutzer, Approval of Equal Rights and Gender Differences in Well-Being, July 2004

1246 Paolo M. Panteghini, Wide vs. Narrow Tax Bases under Optimal Investment Timing, July 2004

1247 Marika Karanassou, Hector Sala, and Dennis J. Snower, Unemployment in the European Union: Institutions, Prices, and Growth, July 2004

1248 Engin Dalgic and Ngo Van Long, Corrupt Local Government as Resource Farmers: The Helping Hand and the Grabbing Hand, July 2004

1249 Francesco Giavazzi and Guido Tabellini, Economic and Political Liberalizations, July 2004

1250 Yin-Wong Cheung and Jude Yuen, An Output Perspective on a Northeast Asia Currency Union, August 2004

1251 Ralf Elsas, Frank Heinemann, and Marcel Tyrell, Multiple but Asymmetric Bank Financing: The Case of Relationship Lending, August 2004

1252 Steinar Holden, Wage Formation under Low Inflation, August 2004

1253 Ngo Van Long and Gerhard Sorger, Insecure Property Rights and Growth: The Roles of Appropriation Costs, Wealth Effects, and Heterogeneity, August 2004

1254 Klaus Wälde and Pia Weiß, International Competition, Slim Firms and Wage Inequality, August 2004

1255 Jeremy S. S. Edwards and Alfons J. Weichenrieder, How Weak is the Weakest-Link Principle? On the Measurement of Firm Owners' Control Rights, August 2004

1256 Guido Tabellini, The Role of the State in Economic Development, August 2004 
1257 François Larmande and Jean-Pierre Ponssard, EVA and the Controllability-congruence Trade-off: An Empirical Investigation, August 2004

1258 Vesa Kanniainen and Jenni Pääkkönen, Anonymous Money, Moral Sentiments and Welfare, August 2004

1259 Panu Poutvaara and Andreas Wagener, Why is the Public Sector More Labor-Intensive? A Distortionary Tax Argument, August 2004

1260 Lars P. Feld and Stefan Voigt, Making Judges Independent - Some Proposals Regarding the Judiciary, August 2004

1261 Joop Hartog, Hans van Ophem, and Simona Maria Bajdechi, How Risky is Investment in Human Capital?, August 2004

1262 Thomas Eichner and Rüdiger Pethig, Efficient Nonanthropocentric Nature Protection, August 2004

1263 David-Jan Jansen and Jakob de Haan, Look Who's Talking: ECB Communication during the First Years of EMU, August 2004

1264 David F. Bradford, The X Tax in the World Economy, August 2004

1265 Hans-Werner Sinn, Migration, Social Standards and Replacement Incomes. How to Protect Low-income Workers in the Industrialized Countries against the Forces of Globalization and Market Integration, August 2004

1266 Wolfgang Leininger, Fending off one Means Fending off all: Evolutionary Stability in Submodular Games, August 2004

1267 Antoine Bommier and Bertrand Villeneuve, Risk Aversion and the Value of Risk to Life, September 2004

1268 Harrie A. A. Verbon and Lex Meijdam, Too Many Migrants, Too Few Services: A Model of Decision-making on Immigration and Integration with Cultural Distance, September 2004

1269 Thomas Eichner and Rüdiger Pethig, Economic Land Use, Ecosystem Services and Microfounded Species Dynamics, September 2004

1270 Federico Revelli, Performance Rating and Yardstick Competition in Social Service Provision, September 2004

1271 Gerhard O. Orosel and Klaus G. Zauner, Vertical Product Differentiation When Quality is Unobservable to Buyers, September 2004

1272 Christoph Böhringer, Stefan Boeters, and Michael Feil, Taxation and Unemployment: An Applied General Equilibrium Approach, September 2004 
1273 Assaf Razin and Efraim Sadka, Welfare Migration: Is the Net Fiscal Burden a Good Measure of its Economics Impact on the Welfare of the Native-Born Population?, September 2004

1274 Tomer Blumkin and Volker Grossmann, Ideological Polarization, Sticky Information, and Policy Reforms, September 2004

1275 Katherine Baicker and Nora Gordon, The Effect of Mandated State Education Spending on Total Local Resources, September 2004

1276 Gabriel J. Felbermayr and Wilhelm Kohler, Exploring the Intensive and Extensive Margins of World Trade, September 2004

1277 John Burbidge, Katherine Cuff and John Leach, Capital Tax Competition with Heterogeneous Firms and Agglomeration Effects, September 2004

1278 Joern-Steffen Pischke, Labor Market Institutions, Wages and Investment, September 2004

1279 Josef Falkinger and Volker Grossmann, Institutions and Development: The Interaction between Trade Regime and Political System, September 2004

1280 Paolo Surico, Inflation Targeting and Nonlinear Policy Rules: The Case of Asymmetric Preferences, September 2004

1281 Ayal Kimhi, Growth, Inequality and Labor Markets in LDCs: A Survey, September 2004

1282 Robert Dur and Amihai Glazer, Optimal Incentive Contracts for a Worker who Envies his Boss, September 2004

1283 Klaus Abberger, Nonparametric Regression and the Detection of Turning Points in the Ifo Business Climate, September 2004

1284 Werner Güth and Rupert Sausgruber, Tax Morale and Optimal Taxation, September 2004

1285 Luis H. R. Alvarez and Erkki Koskela, Does Risk Aversion Accelerate Optimal Forest Rotation under Uncertainty?, September 2004

1286 Giorgio Brunello and Maria De Paola, Market Failures and the Under-Provision of Training, September 2004

1287 Sanjeev Goyal, Marco van der Leij and José Luis Moraga-González, Economics: An Emerging Small World?, September 2004

1288 Sandro Maffei, Nikolai Raabe and Heinrich W. Ursprung, Political Repression and Child Labor: Theory and Empirical Evidence, September 2004 
1289 Georg Götz and Klaus Gugler, Market Concentration and Product Variety under Spatial Competition: Evidence from Retail Gasoline, September 2004

1290 Jonathan Temple and Ludger Wößmann, Dualism and Cross-Country Growth Regressions, September 2004

1291 Ravi Kanbur, Jukka Pirttilä and Matti Tuomala, Non-Welfarist Optimal Taxation and Behavioral Public Economics, October 2004

1292 Maarten C. W. Janssen, José Luis Moraga-González and Matthijs R. Wildenbeest, Consumer Search and Oligopolistic Pricing: An Empirical Investigation, October 2004

1293 Kira Börner and Christa Hainz, The Political Economy of Corruption and the Role of Financial Institutions, October 2004

1294 Christoph A. Schaltegger and Lars P. Feld, Do Large Cabinets Favor Large Governments? Evidence from Swiss Sub-Federal Jurisdictions, October 2004

1295 Marc-Andreas Mündler, The Existence of Informationally Efficient Markets When Individuals Are Rational, October 2004

1296 Hendrik Jürges, Wolfram F. Richter and Kerstin Schneider, Teacher Quality and Incentives: Theoretical and Empirical Effects of Standards on Teacher Quality, October 2004

1297 David S. Evans and Michael Salinger, An Empirical Analysis of Bundling and Tying: Over-the-Counter Pain Relief and Cold Medicines, October 2004

1298 Gershon Ben-Shakhar, Gary Bornstein, Astrid Hopfensitz and Frans van Winden, Reciprocity and Emotions: Arousal, Self-Reports, and Expectations, October 2004

1299 B. Zorina Khan and Kenneth L. Sokoloff, Institutions and Technological Innovation During Early Economic Growth: Evidence from the Great Inventors of the United States, 1790 - 1930, October 2004

1300 Piero Gottardi and Roberto Serrano, Market Power and Information Revelation in Dynamic Trading, October 2004

1301 Alan V. Deardorff, Who Makes the Rules of Globalization?, October 2004

1302 Sheilagh Ogilvie, The Use and Abuse of Trust: Social Capital and its Deployment by Early Modern Guilds, October 2004 